NBER WORKING PAPER SERIES

\title{
एயس ETHNIC COMPLEMENTARITIES AND THE POLITICAL CONTAGION OF PEACE AND CONFLICT IN GUJARAT
}

\author{
Saumitra Jha \\ Working Paper 19203 \\ http://www.nber.org/papers/w19203
NATIONAL BUREAU OF ECONOMIC RESEARCH
1050 Massachusetts Avenue
Cambridge, MA 02138
July 2013

I owe much thanks to Ken Arrow, Susan Athey, Prashant Bharadwaj, Avner Greif, Dan Hungerman, Lakshmi Iyer, Kimuli Kasara, David Laitin, Jessica Leino, Asim Khwaja, Atif Mian, Aprajit Mahajan, Steven Wilkinson and seminar participants at AALIMS, Berkeley, Chicago, Clio, Davis, the Erasmus University Rotterdam, Harvard, the Hebrew University of Jerusalem, Northwestern, Stanford, LiCEP, LSE, MIT, Princeton, the NBER Conference on Religion and Culture, NEUDC, NYU, Rochester, UBC, USC, UWO, the all-UC economic history group and the World Bank for useful comments and suggestions and the Stanford Institute for Economic Policy Research, the Harvard Academy, and the Center for Study of Democratic Politics and the Niehaus Center for Globalization and Governance at Princeton for support. The views expressed herein are those of the author and do not necessarily reflect the views of the National Bureau of Economic Research.

NBER working papers are circulated for discussion and comment purposes. They have not been peerreviewed or been subject to the review by the NBER Board of Directors that accompanies official NBER publications.

(C) 2013 by Saumitra Jha. All rights reserved. Short sections of text, not to exceed two paragraphs, may be quoted without explicit permission provided that full credit, including $(\mathrm{C}$ notice, is given to the source. 
"Unfinished Business": Ethnic Complementarities and the Political Contagion of Peace and Conflict in Gujarat

Saumitra Jha

NBER Working Paper No. 19203

July 2013

JEL No. N0,N3,N35,N4,N45,N9,N95,O1,O12,R1,Z1,Z12,Z13

\begin{abstract}
I examine how the historical legacies of inter-ethnic complementarity and competition influence contemporary electoral competition and its effects on patterns of ethnic violence. Using local comparisons within Gujarat, a single Indian state known for its non-violent local traditions yet also for widespread ethnic pogroms in 2002, I provide evidence that while towns with close votes in the preceding state elections do predict an increased incidence of ethnic riots, these effects are diminished in medieval port towns that historically enjoyed exogenous inter-ethnic complementarities. Furthermore, unlike other towns where pre-riot electoral competitiveness coincided with historic inter-ethnic competition and where the ruling party reaped well-targeted electoral dividends from the riots, medieval port constituencies exhibited a relative vote swing of more than seven percentage points against that party. These rendered medieval port constituencies marginal constituencies in future elections, which also saw less ethnic violence.

I interpret these results as consistent with the existence of a fundamentally conditional, yet magnifying interaction between electoral competition and local institutions in generating incentives for ethnic violence. Where marginal electoral constituencies coincide with or reflect pre-existing inter-ethnic economic competition, politicians have both enhanced local and state-wide incentives to foster ethnic mobilization and violence. On the other hand, when the focus of electoral competition shifts to constituencies enjoying complementary norms and organizations supporting local inter-ethnic tolerance, this can reduce state-wide incentives for ethnic violence.
\end{abstract}

Saumitra Jha

Stanford University

saumitra@gsb.stanford.edu 


\section{Introduction}

On February 27th, 2002, a carriage of the Sabarmati Express carrying Hindu activists caught fire at Godhra railway station in the western Indian state of Gujarat. At least 58 people were burnt alive. Named for Mahatma Gandhi's centre for non-violence located at its destination, the city of Ahmadabad, the burning of the Sabarmati Express precipitated weeks of violent ethnic rioting between Hindus and Muslims throughout the state that claimed at least a thousand lives between February and the end of April, 2002, and forced at least 98,000 people into refugee camps. Many of the riots appeared to have been planned in advance, targeting the businesses and all too often the lives of ethnicities that were minorities within each locality, a large majority of these being Muslim. ${ }^{1}$

The complicity of the ruling Bharatiya Janata Party (BJP) state government, an organization with strong historic ties to Hindu nationalists (Hansen, 1999), was suspected, as accounts of pogroms led by local members of the legislative assembly (MLAs) and close advisors to the Chief Minister rapidly surfaced. ${ }^{2}$ The ruling party dissolved the 187 seat state assembly in July 2002, ten months early, and in the subsequent state elections, their vote share rose by an average 4.84 percentage points, gaining them 10 seats. One high-ranking police official, who chose to be anonymous, told the author in 2007 that the Gujarat violence was 'unfinished business' from India's long history of inter-ethnic relations, particularly from the incomplete ethnic cleansing that occurred during the Partition of South Asia in 1947. He claimed that many in the government believed that by allowing the violence to happen once, it would not happen again. Following the 2002 pogroms, the number of riot incidents recorded in the state have indeed fallen considerably even relative to their pre-2002 levels, despite the fact that elections were on average more, not less, competitive (Figure 1). ${ }^{3}$

The incentives for political figures to encourage mobilization on ethnic lines in order to swing close elections has been observed in settings around the world, including Africa (eg

\footnotetext{
${ }^{1}$ Lists of Muslim-owned businesses were prepared in advance in a number of areas, often through the use of local surveys. These were sometimes adhered to even in when they had become obsolete or were inaccurate, such as in the town of Himmatnagar where the businesses of Hindus who had recently bought out Muslim businesses were also destroyed despite their protests (People's Union for Democratic Rights, 2002).

${ }^{2}$ In 2012, the BJP MLA and state minister Maya Kodnani was ultimately convicted for her role in the massacre of Muslims in Naroda Patiya and sentenced to 28 years in jail. Testimony collected by the People's Union for Democratic Rights (2002) also implicated local BJP MLAs in Delol, Sanjeli and Visnagar. At the same time, while Muslim-majority areas were placed under strict curfew, state law enforcement appears to have shown an asymmetric unwillingness to intervene during mob violence led by Hindus (People's Union for Democratic Rights, 2002).

${ }^{3}$ The ratio of the vote share between winners and losers actually declined from 1.74 to 1.25 in medieval port constituencies and 1.51 to 1.46 in non-medieval port towns between the 1998 and 2002 elections. Even in 2007, the races remained closer than 1998- the ratio being close to 1.45 in both medieval port and non-medieval port towns. See also Table 1.
} 
Eifert, Miguel and Posner, 2010), the United States (Olzak, 1992) and South Asia (Blakeslee, 2013, Wilkinson, 2004, Brass, 1997). Indeed, ethnic heterogeneity and polarization has been associated with reduced public goods provision, lowered growth and increased civil conflict (eg Easterly and Levine, 1997, Alesina and La Ferrara, 2005, Montalvo and ReynalQuerol, 2005). And in the many developing country environments where ethnic parties favor their own with patronage (eg Chandra, 2007, Banerjee, Iyer and Somanathan, 2008), ethnic cleansing may itself act as a response to anticipated inter-ethnic electoral competition (Jha and Wilkinson, 2012).

Yet, much less is known about the conditions under which poor ethnically diverse societies remain peaceful even in the presence of strong political incentives for violence. In this paper, I examine how different types of "unfinished business"-historical legacies of inter-ethnic complementarity, competition and ethnic cleansing- influence the distribution of electoral competitiveness, and in turn the effects of electoral competition on violence. I focus upon local comparisons of towns within districts of the western Indian state of Gujarat. Gujarat provides a useful environment to study these questions as it could easily fit within a square of 340 miles and enjoys recorded historical interactions between Hindus and Muslims going back at least to the eighth century, but despite being one of India's wealthiest states and harbouring remarkable traditions of peaceful coexistence and non-violent political mobilisation, towns throughout Gujarat have also become notorious for terrible ethnic pogroms.

I draw upon work by Jha (forthcoming) who describes how overseas trade in the Indian Ocean was coordinated by Muslim pilgrimages, particularly the Hajj, inducing a thousand years of inter-ethnic complementarities between Hindu producers and Muslim traders at small indentations in the coast that formed 'natural harbours' on the medieval coastline. I complement Jha's sub-continent wide study of riots over a 150 year period by restricting the sample geographically and culturally to nearby towns drawn from a single state, and temporally to a single two month period of ethnic riots between February and April 2002. Using a novel set of data on Gujarati towns spanning its medieval, colonial and modern electoral history, I confirm that relative to other Gujarati towns, its medieval ports also appear to be located at arguably exogenous medieval-era indentations. Further, despite being larger and more ethnically diverse, Gujarati medieval ports experienced 30\% fewer days of rioting than otherwise similar towns during the riots between February and April, 2002 .

I next go beyond this work to study the interaction between local institutions and electoral competition. I find, consistent with the literature on elections and ethnic mobilization, that towns with close votes in the 1998 elections for Gujarat's state legislature that preceded the 2002 violence experienced an increased incidence of ethnic riots (eg Wilkinson and Haid, 


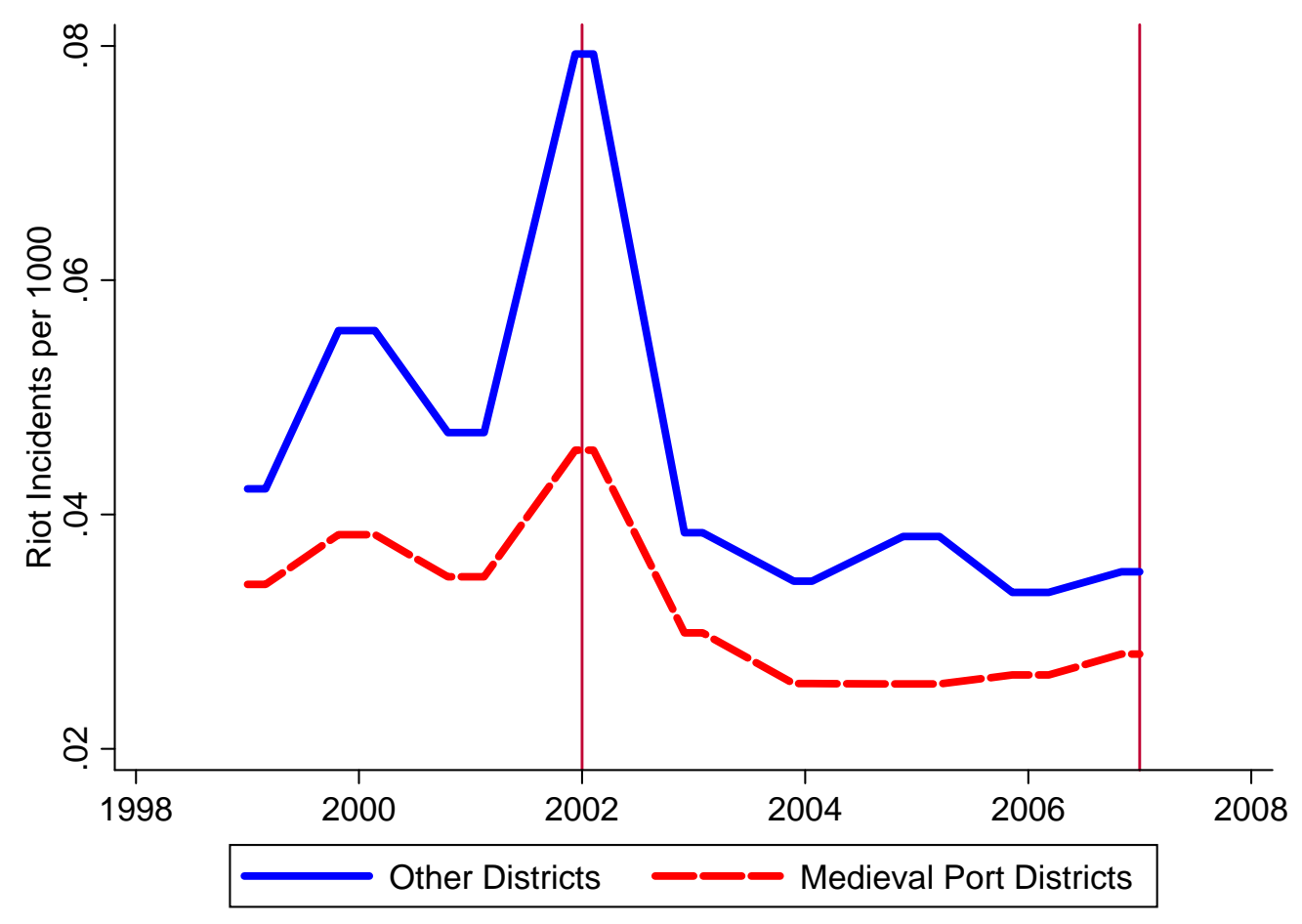

Figure 1: Riot Incidents per 1000 in police districts, by medieval port

source: Crime in India, various volumes, National Crime Records Bureau (NCRB). Riots in Gujarat spiked in 2002 but have fallen below their pre-2002 levels since across the state. Reference lines represent state election years. Medieval port districts have consistently enjoyed fewer riots relative to their population (NB: NCRB statistics include all riots, including those unrelated to Hindu-Muslim violence.) 
2009). However, I also show that a historic legacy of inter-ethnic trade reduced the duration of riots the most in towns that housed competitive races. Furthermore, and unlike otherwise similar towns where the ruling party enjoyed electoral gains following the violence, medieval port constituencies, despite on average slightly preferring the ruling party prior to the electoral violence, exhibited a vote swing of around seven percentage points against that party following the 2002 pogroms. These swings were pivotal enough to lead to a loss to the ruling party of three seats, while also making medieval ports contested 'marginal' constituencies in the elections that followed. Figures 2, 3 and 4 provide visual previews of these results.

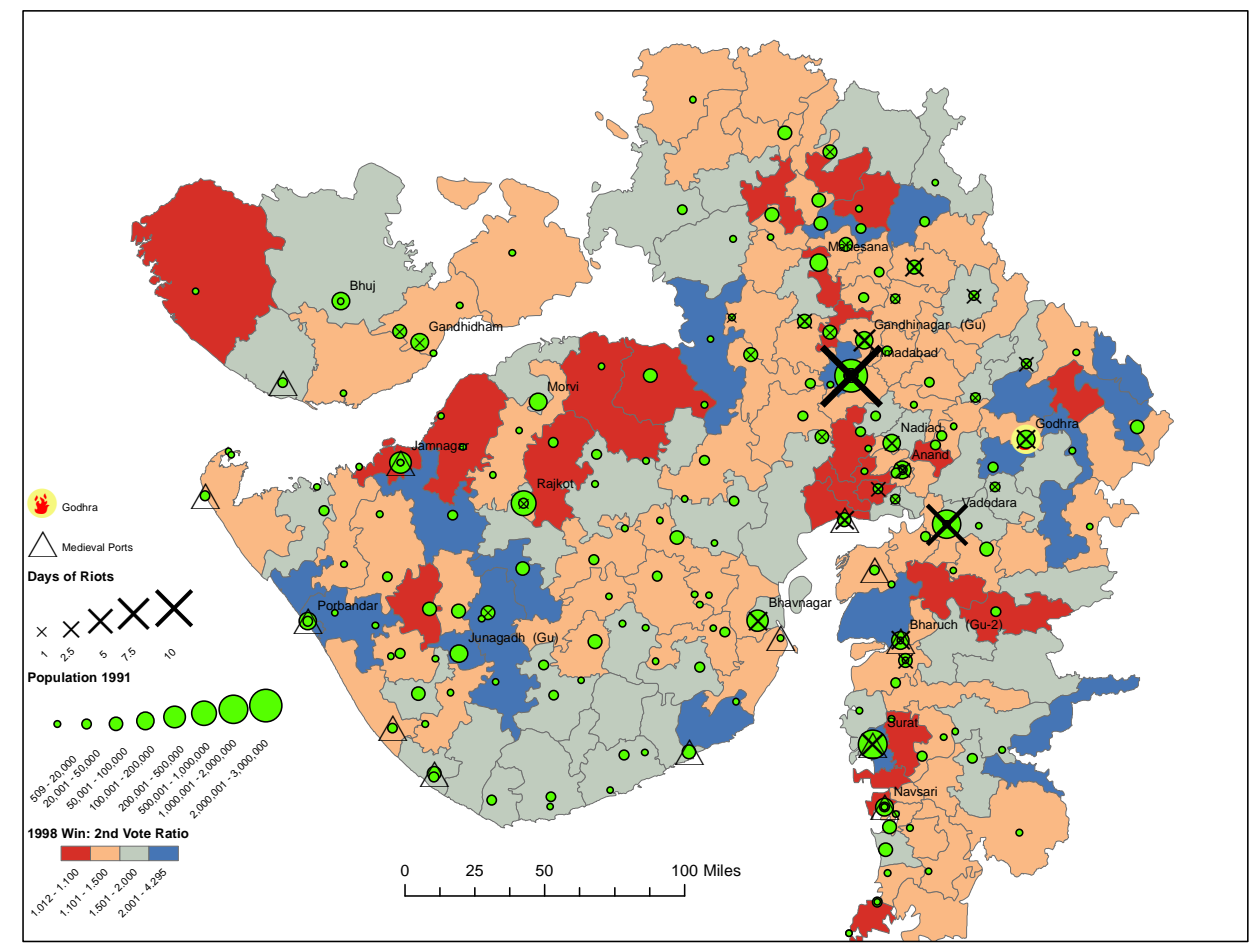

\section{Figure 2: Close Races: Winner-Runner Up Vote Share Ratios, 1998}

Party competition appears to have influenced the propensity for local riots. However, medieval ports experienced both less rioting in general, and less rioting than nearby towns of equivalent size with the same degree of party competition.

I contrast the patterns of violence and electoral competition among societies with histories of inter-ethnic complementarity with other nearby towns which were founded by Muslims or faced a longer history of Muslim political rule- both of which, I argue, generated historical incentives for inter-ethnic competition for political patronage, and thus where historical incentives to engage in violence to reduce future competition were also likely greater. I show that these factors were key determinants of closer electoral races in the elections preceding 


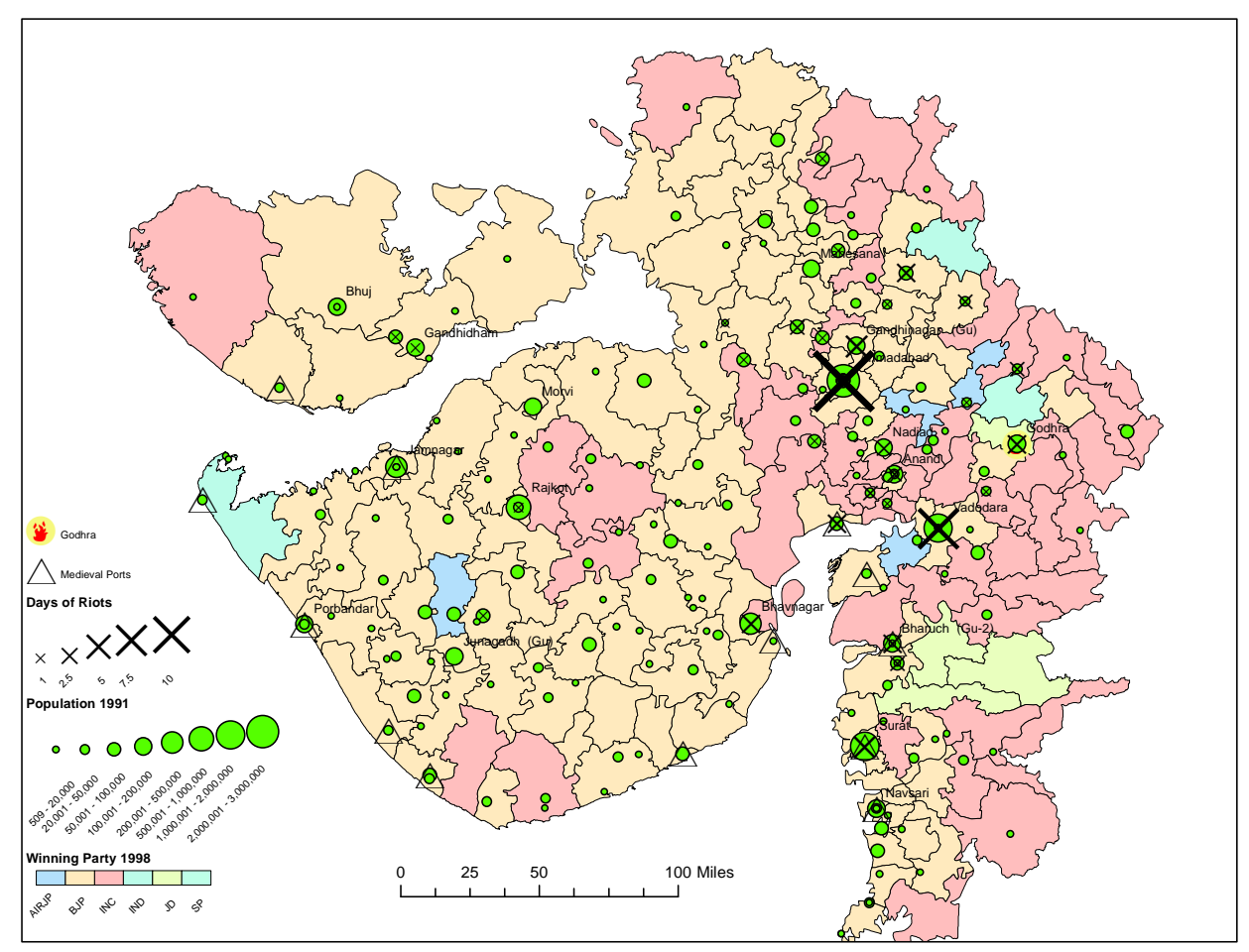

(a) 1998

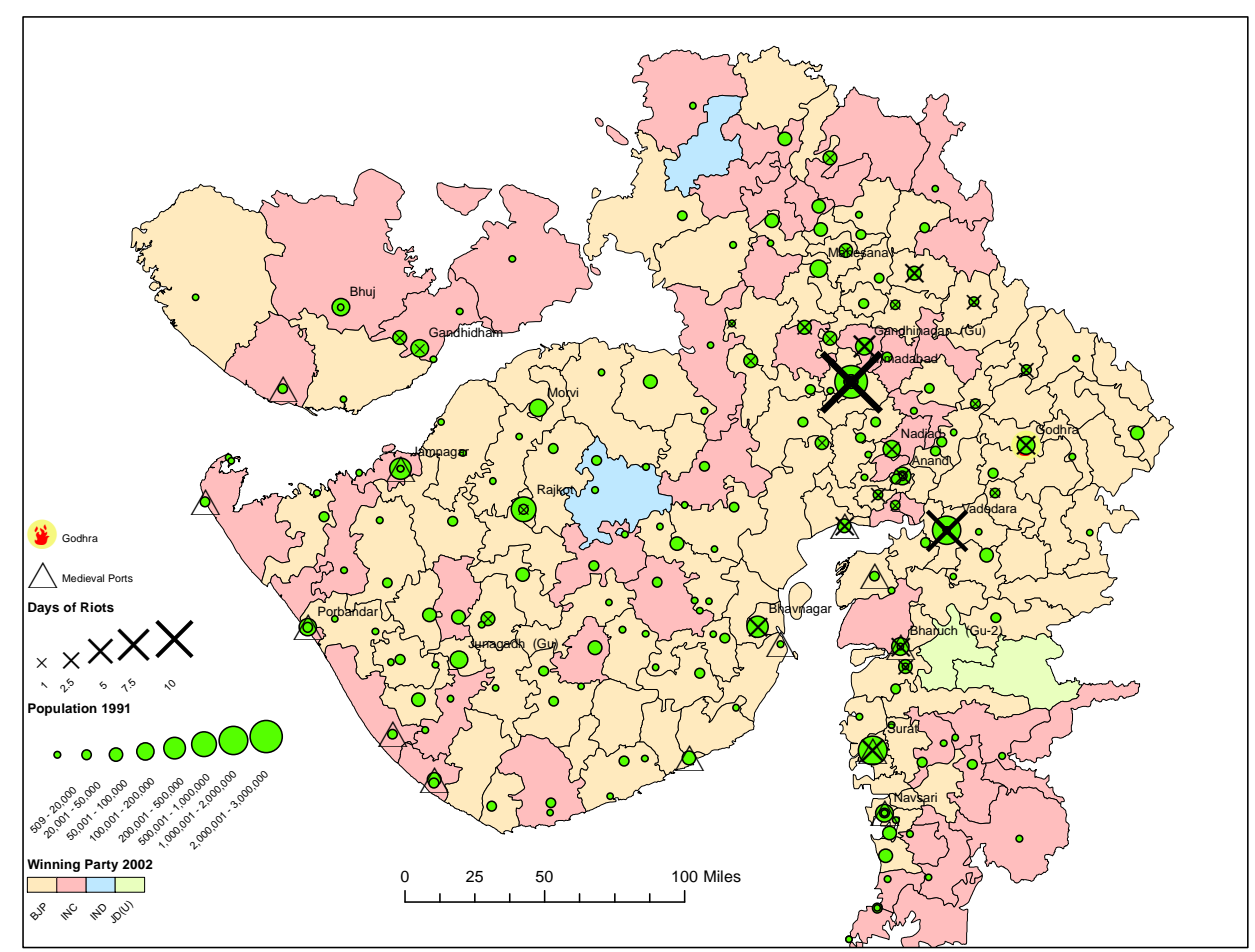

(b) 2002

Figure 3: Seats in the State Legislature Before and After the 2002 Riots

While the ruling party, the BJP, gained in other towns in the 2002 post-violence elections, the party lost seats to Congress (INC) in medieval ports which had previously seated BJP MLAs. 


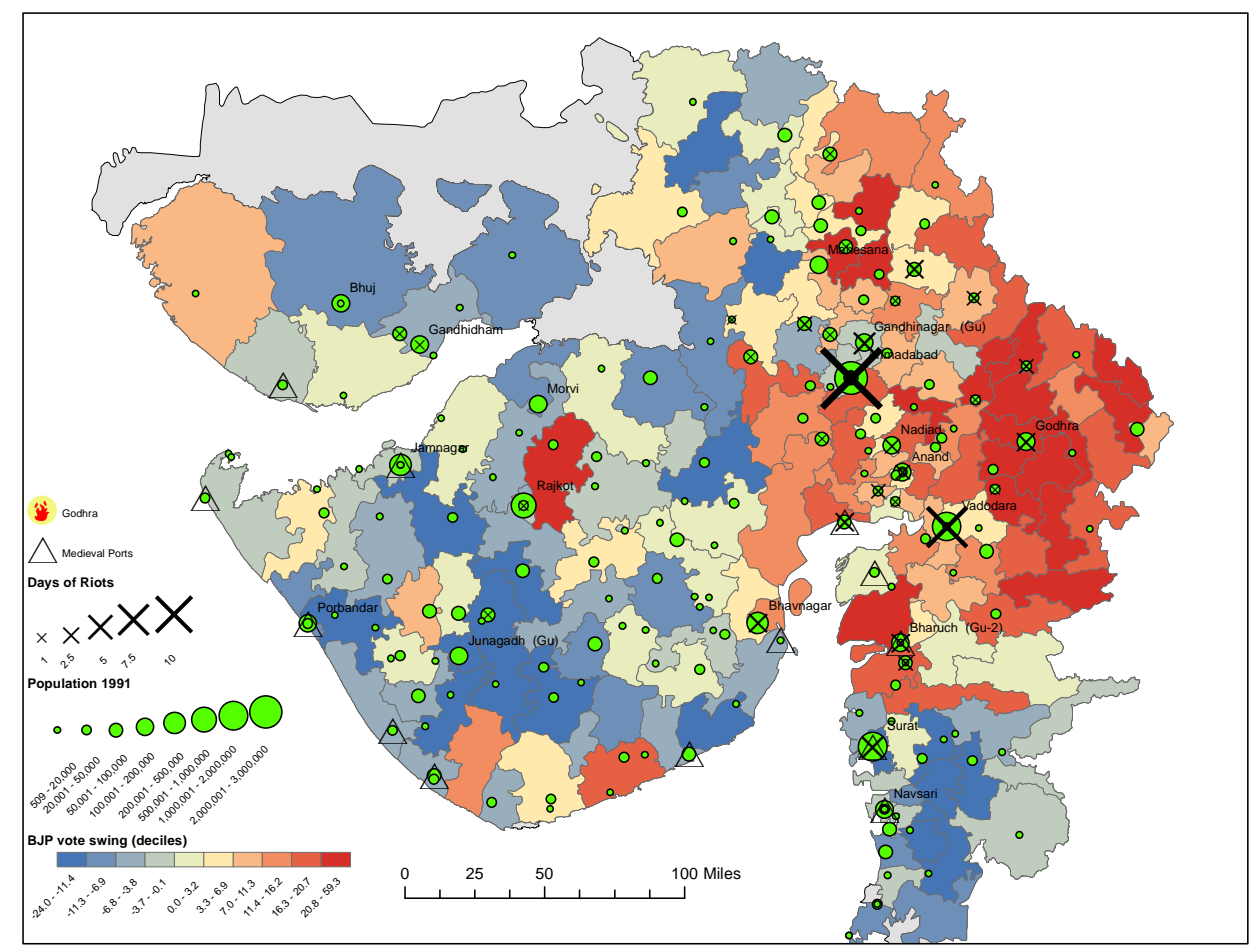

(a) Change in BJP vote share, 1998-2002

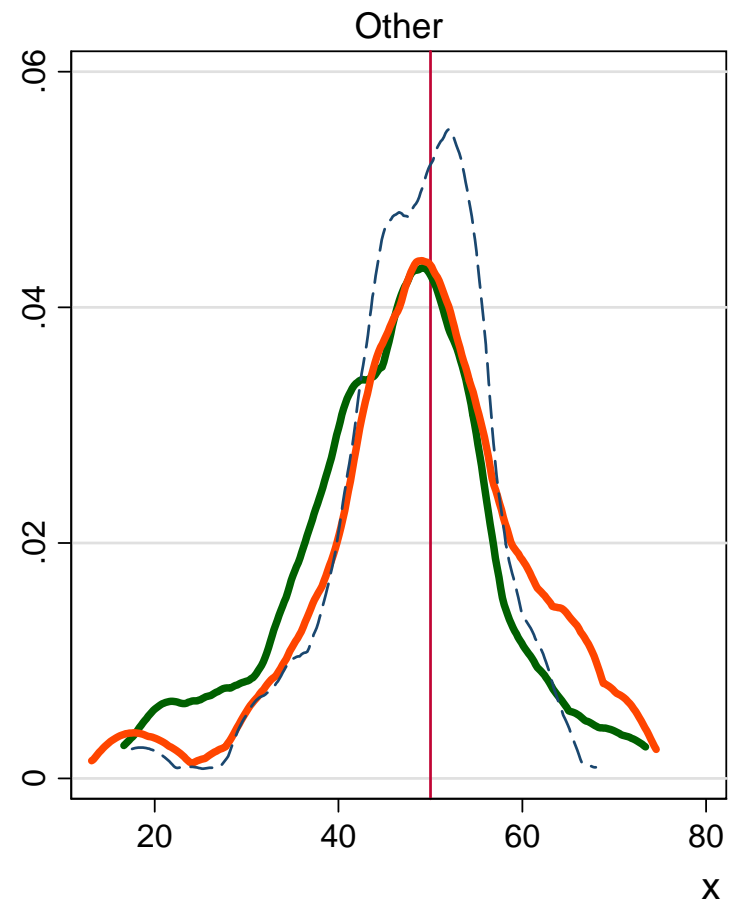

Medieval Port Constituencies

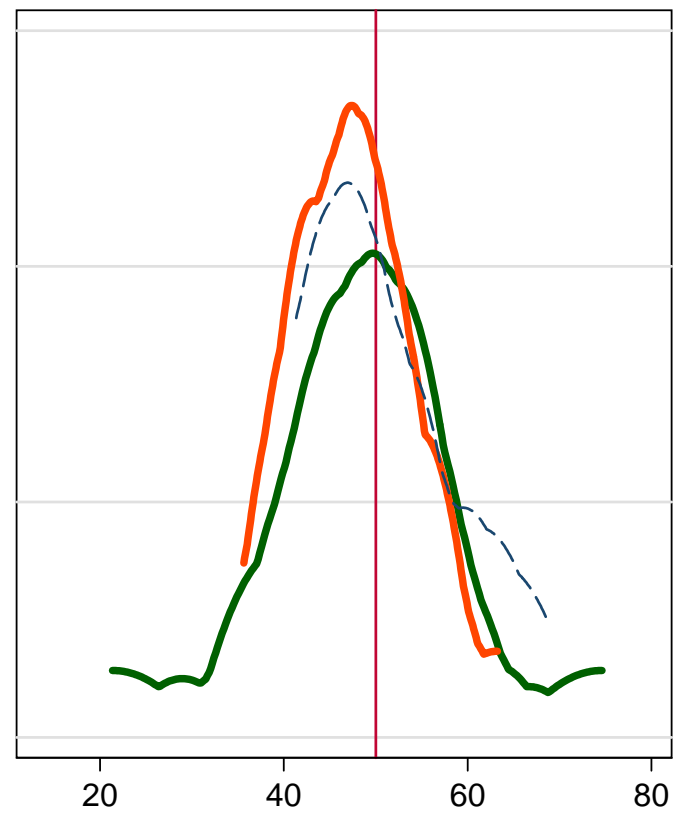

1998

$2002-----2007$

(b) BJP vote share by Medieval Port

Figure 4: Change in Ruling Party Vote Share, 1998-2002

Relative to other towns where the BJP gained vote share following the riots, medieval ports swang against the BJP and became more competitive following the 2002 elections. 
the 2002 riots, and predictors of the districts that experienced more days of rioting themselves. In fact, an additional century of Muslim rule led towns to swing 3.82 percentage points to the BJP in the aftermath of the riots, reflecting either ethnic cleansing of nonsupporters or the retrospective support of voters in these districts of the ethnic riots. The distribution of the ruling party vote share gains in the elections following the riots also appear to be relatively 'efficiently' targeted from the perspective of the state party, gaining in these marginal constituencies even at the cost of losses in vote share in inframarginal constituencies. Ironically, these vote swings have resulted in towns of historical inter-ethnic patronage competition changing status from electorally competitive in 1998 to inframarginal in subsequent elections.

I interpret these results as reflecting the fundamentally conditional nature of the relationship between electoral competition and ethnic violence. In environments where groups compete economically, close electoral competition may provide enhanced incentives to local politicians to exacerbate pre-existing inter-ethnic tension that can readily lead to local violence. However, the presence of inter-ethnic complementarity or institutional mechanisms that support inter-ethnic cooperation appears to have its strongest mitigating effect where the incentives for political violence are also the strongest.

Furthermore, shifts in the location of electoral competition appear to have magnifying spillovers between local and state-wide political incentives. In societies where state parties compete for marginal constituencies characterised by pre-existing inter-ethnic competition, parties have enhanced incentives to emphasise the preferences of these voters in particular, even at the expense of other more less ethnically polarized constituents. This may lead state parties not only to encourage and allow local ethnic violence, but to adopt a permissive stance to violence elsewhere as well. This appears to fit Gujarat's story during the 2002 pogroms.

I argue, however, that the consolidation of medieval port constituencies as those of heightened electoral competition in the post-pogrom period, and the coincident falls in rioting across the state (Figure 1), despite there being well-established institutional riot systems' (Brass, 2003), a state government demonstratedly sympathetic to ethnic violence and greater electoral competition in the average constituency, are suggestive that the corollary is true as well: state politicians seeking to compete in marginal constituencies with strong local institutions of tolerance have incentives to emphasise these voters' preferences more relative to their more polarized constituents, leading potentially to a de-escalation in state-wide platforms of ethnic hatred. In this way, when constituencies with historical interethnic complementarities become electorally competitive, this may have led not just to lower local violence but to positive spillovers throughout the state, as state-level politicians gain 
enhanced incentives to moderate their platforms and prevent ethnic violence. The shifting locations of strong electoral competition in Gujarat from towns where ethnicities competed to towns where they enjoyed complementary business relationships may thus explain the rapid change of the Hindu nationalist state government from a party whose platform was strongly centered on ethnic mobilization prior to the 2002 elections to a more moderate platform which has de-emphasised ethnic mobilization and has kept riots in check.

Beyond the papers already mentioned, this paper builds upon an important set of wellestablished literatures in economics and political science, including those examining the determinants and the effects of close elections, the effects of religious intensity and ethnic identification on voting, and the corresponding incentives by political figures to foster ethnic mobilization. Esteban and Ray (2007) present a model where elites from ethnic majorities benefit from providing resources for poor members of their group to riot against minorities to avoid class conflict. This resonates with Glaeser (2005)'s analysis of how incentives for politicians to send hate messages in the US South increased with calls for redistribution. More generally, Canes-Wrone, Herron and Shotts (2001) show that in competitive elections, local politicians have greater incentives to 'pander' to voters' sentiments by publicly advocating popular policies that they personally know will not be socially beneficial. ${ }^{4}$

In the South Asian context, Brass (1997) describes how politicians in old Indian cities develop 'institutionalized' riot systems to mobilize their base on ethnic lines. ${ }^{5}$ Wilkinson (2004) provides evidence that states with greater inter-party competition- settings where Muslims are more likely to be electorally pivotal- are less likely to exhibit electoral violence. At the same time, Wilkinson and Haid (2009), also looking at constituencies in Gujarat in 2002, find a correlation between close races in the state legislature (the Vidhan Sabha) elections in 1998 and the subsequent propensity for riots. Similarly, Pathania and Tandon (2011) take a sample of riots in India between 1989 and 1995, and find that the killing was more intense where the BJP won in contested national (Lok Sabha) elections between 1989-91. Blakeslee (2013) finds that the BJP was more likely to direct the 'Rath Yatra'- a procession originating in Gujarat aimed at religious mobilization- at marginal constituencies that subsequently experienced greater rioting. Instead, Varshney (2002) describes how towns with 'civic engagement'- the development of organizations and social norms conducive to peace- also reveal a lack of violence. This paper complements and unifies these works by examining the exogenous historical antecedents of ethnic polarization and electoral com-

\footnotetext{
${ }^{4}$ Close races and religiosity also appear to affect mobilisation. Cox and Munger (1989) show that higher expenditures on mobilization efforts occur in close races in the US Congress. At the same time, Gerber, Gruber and Hungerman (2010) show that shocks that lower the costs of engaging in religious practice raise voter turnout.

${ }^{5}$ See also Jha (2013) who describes how electoral incentives were a likely precipitant of riots against Tata's Nano plant in West Bengal.
} 
petition and establishing the conditional, yet reinforcing, role of political competition on violence when economically competitive constituencies become marginal on one hand and the potential state-wide spillover effects of electoral competition in also reducing incentives of violence when societies with local institutions of inter-ethnic tolerance become electorally competitive on the other.

This paper also builds upon and contributes to an important literature that exploits local geographical comparisons and finds that historical exposure to different political institutional environments, particularly empires, past incidents of violence or propensities for inter-ethnic trade, can have lasting effects on traits as diverse as financial development (Guiso, Sapienza and Zingales, 2008, Grosjean, 2012), trust in bureaucracy (Becker, Boeckh, Hainz and Woessmann, 2012) contemporary attitudes towards religion, voting and democracy (Grosfeld and Zhuravskaya, 2012), and differences in ethnic assimilation, hatred, tolerance and trust (Voigtländer and Voth, 2011, Nunn and Wantchekon, forthcoming, Jha, 2008, forthcoming, Diaz-Cayeros and Jha, 2013). This paper adds to these works by showing how modern electoral incentives can strengthen or undermine the effects of such historical cultural and institutional legacies.

This paper also suggests a direction for additional nuance to an important and illuminating series of papers that exploits proposed quasi-random variation in close races to identify the benefits of slight winners of particular ethnic identities relative to slight losers. Based as they are upon such local comparisons, these studies have naturally focused been ahistorical

for the most part. Yet, just as the close races in Gujarat appear to have moved due to its pogroms from historically polarized to historically tolerant communities, the extent to which regression discontinuity measures reflect local or global phenomena, the likelihood that unobserved 'waves' may upset covariate balance and the measured effects of slight victories are likely to depend and interact in important ways with pre-existing patterns of ethnic polarization, past ethnic cleansing and local institutions. ${ }^{6}$

I begin by providing brief historical and contextual background on ethnic relations in Gujarat, that also serves to motivate the identification strategy and interpretation, and introduce the data. I next provide the main empirical results before concluding.

\section{Historical Context}

Gujarat is one of India's wealthiest states, its modern borders demarcated to leave it linguistically homogeneous and made mostly of flat plains and marsh that could fit easily within a

\footnotetext{
${ }^{6}$ This has parallels with evidence that in United States congressional races since 1946, the victors of close races in any given year, rather than being random, are largely predictable by broader 'waves' in electoral behaviour (Caughey and Sekhon, 2011).
} 
square of 340 miles (Figure 5). The riots that followed the burning of the Sabarmati Express at Godhra, though initially concentrated near that city, rapidly spread to towns throughout the state as it became clearer that the state government and police were either complicit or at least unlikely to intervene. In Porbandar, a medieval port on the western coast, a respondent mentioned that attempts were made to instigate violence by outsiders, who sent women's bangles to the members of the Hindu community as a symbol of their lack of masculinity in not joining the riots [author's field observations, 2006-7]. Bangles were delivered to other communities in the state as well. ${ }^{7}$

Yet, not every community responded to the bangles with violence. Gujarat shows great diversity in its inter-ethnic relations, both historically and as historical incentives manifest themselves in modern political behaviour. With 14\% of India's coastline, Gujarat has housed centers of commerce trading to the Middle East even before the rise of Islam (Casson, ed, 1989), and has a history of political rule by Muslims that goes back to the 11th century. Hindus and Muslims within Gujarati towns have long faced highly differing incentives to interact and to develop means to mitigate, and sometimes also propagate, ethnic violence.

I build upon work by Jha (2008, forthcoming), who documents the fact that, due to the coordination of overseas trade throughout Muslim pilgrimage, including the Hajj, which made Mecca the largest textile market in the world, Muslim seafarers throughout the Indian Ocean - who naturally had preferred access to their own pilgrimage routes- enjoyed exogenous, non-replicable complementarities with local communities in inter-ethnic trade. Furthermore, because trade was coordinated by the pilgrimage, it was relatively easy for any Muslim to enter, and intra-Muslim competition limited the potential for monopsonistic rents. Mutual incentives existed among local communities in medieval ports to develop systems of norms, beliefs and organizations that reinforced inter-ethnic trust and tolerance. Jha (forthcoming) shows that medieval ports which were the geographical focuses of these historic complementarities between Hindus and Muslims reveal lasting reductions in ethnic violence across the towns of the sub-continent between 1850 and 1995. Jha provides case and household level survey evidence in support of a number of institutional mechanisms: Muslims in medieval ports have continued to be specialised in complementary roles coordinated by their religious leadership,show enhanced propensities to join such religious organizations, show enhanced propensities to vaccinate their sons against polio- a behavioural measure of trust in the majority community- and report less exposure to ethnic conflict in their communities.

It is useful to provide brief, concrete, examples of the institutional legacies of medieval

\footnotetext{
${ }^{7}$ See, for example, the description of riots in the village of Sanjeli, Dohad district, by the People's Union for Democratic Rights (2002).
} 
trade and their spillover effects throughout the state. In the non-medieval port town of Santrampur, near Godhra, Muslims in the Sant locality witnessed the arrivals of Hindu mobs of 150 on the 28th of February and 2500 on the 3rd of March, containing many that they recognized from among their neighbours. While most Muslims were able to flee, two were hacked to death by swords while trying to escape, and two mosques, a madrassa and a dargah (a tomb of a local Muslim saint) were destroyed (People's Union for Democratic Rights, 2002).

Yet, approximately one mile from these events, another mixed Hindu-Muslim area housed a temple of the Pranami sect of Hinduism. The Hindu community offered protection to their Muslim neighbours, who chose not to flee and were not attacked (Burman, 2005)[pg.106]. The Pranami sect was established in 1651 by Mehraj Thakur, the son of the Diwan (Vizier) of Jamnagar, a medieval port in western Gujarat, who had followed the trading and pilgrimage routes to Basra in Iraq and had returned to organize a syncretic sect that focused on the essential similarities of Islam and Hinduism and the desirability of social interactions between the two. Later called Mahamati Prannath, the sect he founded gained around 3 million adherents around northern India (Burman, 2005)[pg.103].

These included a woman, Putli Ba, who newly married, moved from Jamnagar to another Gujarati medieval port, Porbandar, to join her husband, a native Porbandari. Her son, Mohandas, later recounted to his secretary how:

After my marriage [at age 13], my mother took me to the [local Pranami] temple also. ... There were no idols or images in it; and on the walls there was writing that looked very much like texts from the Koran. The dress that the priests wore was unlike what Hindu priests in temples generally wear and their way of praying also resembled somewhat that of the Muslims (Pyarelal, 1965)[pg214].

Mohandas, later called "Mahatma", Gandhi, raised in Porbandar and Rajkot, would later get his start as a lawyer for Porbandari Muslim merchants in South Africa. He would draw upon Gujarati Hindu and Jain ideals of ahimsa- or non-violence- and arguably also the social traditions of inter-ethnic tolerance among Muslims and Hindus in Gujarati medieval ports in crafting his political message of non-violence.

Thus norms, organizations and beliefs of syncretism and ethnic tolerance, inspired in part by medieval inter-ethnic trade, appear to continue to persist in medieval ports, despite the decline of international trade, and to have spread in varying degrees throughout the state (please see Jha (forthcoming) for detailed case study comparisons of institutions of tolerance developed by Muslim trading communities, such as the Bohras, in Surat relative to Ahmedabad, as well as discussion of other medieval ports). Years later, when asked about the local response to the bangles used to incite violence during the 2002 riots, my 
Porbandari respondent remarked: "This did not work. We didn't want [violence], our police and officials did not want it. Nobody wanted it." [author's field observations, 2006-7]. Porbandar, despite a reputation for gang violence centered around caste-based organized crime, remained peaceful during the Hindu-Muslim riots of $2002 .^{8}$

To proxy for the effect of such historical medieval inter-ethnic complementarities, I will use the location of medieval ports that I can document traded directly to the Middle East in the seventeenth century (please see below). Insofar as the tolerant traditions of these ports have spread both locally, and state-wide, such a proxy approach will result in an underestimate and thus imply a lower bound effect. To address the possibility that the selection of favourable locations for historic trade that may have favourable on contemporary ethnic relations for reasons unrelated to medieval trade, I exploit the fact that because of strong cyclonic activity in the Indian Ocean, medieval ports, much more so than modern ports, depended on being located at 'natural harbours'- small indentations on the medieval coastline.

As Figure 5 suggests, medieval ports relied on 'natural harbours'- small indentations on the medieval coastline- to protect themselves from the strong cyclonic activity in the Indian Ocean. Due to the monsoon rains, furthermore, these natural harbours have had a tendency to silt up over time, exogenously reducing the favourability of medieval ports for trade, even while the Portuguese and British actively sort to divert the flows of global trade to competing ports like Daman and Diu, and later to Bombay. Due to the monsoon rains, furthermore, these natural harbours have had a tendency to silt up over time, exogenously reducing the favourability of medieval ports for trade. The Roman-era Gujarati port of Broach (Barygaza) gave way to Cambay and then Surat due to silt, with Surat itself developing a bar of silt in its main roads which later impeded colonial shipping. In fact, $77 \%$ of Gujarati medieval ports were at such potential natural harbours in the medieval coastline, and 30\% showed no shipping activity in 2002 (see also Table 1 and Figure 5).

But Gujarat's history was not just one of inter-ethnic complementarity between Hindus and Muslims due to trade, but also one of considerable ethnic violence and potential grievance. Though Arabs had conquered neighbouring Sind by amphibious invasion in the early eighth century, one of the first encounters that contemporary India faced of Muslim military power was a notorious raid by the Afghan ruler, Mahmud of Ghazni, on the temple

\footnotetext{
${ }^{8}$ Porbandar became notorious in the 1980s for gang warfare between castes of Kolis and Mers competing over the smuggling of alcohol into the state, which, partly in honour of Gandhi's memory, continues to maintain strict blue laws. Gang leader, Santokben Jadeja, immortalized in the Bollywood gangster movie Godmother, also represented the constituency as its MLA in the 1980s. Though planning to run once more in 2002, she ceded her support to the Congress candidate, in time for him to win in the swing we shall document against the then ruling BJP. See Smruti Koppikar "Gandhi's birthplace turns goons' lair", Hindustan Times, December 11, 2012.
} 
city of Somnath, approximately 70 miles from Porbandar, in 1026. From the time of the chronicler, Alberuni (1030), who accompanied Mahmud, to the modern day, the destruction of the temple has been seen as a 'Kosovo Pole'-like event in Indian history, one that has polarized Hindus and Muslims against each other ever since. ${ }^{9}$

In fact, in direct contrast to the robust complementarities visible at medieval trading ports were the incentives present in towns that were the centres of Muslim political authority, where Hindus and Muslims often acted as substitutes for one another and competitors for patronage. Following the Somnath raid, Muslim rule began to spread into India, and eventually to Gujarat too (Figure 6). With the conquest came control of patronage and land revenue systems, based upon control of the surplus from India's mainly agricultural wealth. These patronage systems were concentrated in towns, like Ahmadabad, which were established by the fiat of the Muslim rulers themselves, as well as existing cities that became the administrative capitals of local rulers, such as Palanpur and the medieval port of Cambay (Raychoudhari, 1998).

In medieval Indian kingdoms, political and religious patronage played a very important role. Though not necessarily members of the royal household themselves, the majority of the city's population was often tied by client relations to people who were. ${ }^{10}$ Once flourishing cities that lost their roles as political centres rapidly became ghost towns.

Following the Muslim conquest, it is likely that Muslim clients, both converts and immigrants, substituted for and competed with Hindu clients for patronage. Though "vertical" inter-ethnic links existed between Hindu artisans and Muslim patrons, such ties were often in competition to intra-Muslim patron-client relations. Though the Hindu and Muslim artisans that constituted the majority of the populations of these cities lived side by side, there was limited incentive for inter-ethnic exchange between these groups. ${ }^{11}$ Thus, despite the fact that, like medieval ports, political centres provided historical incentives for conversion

\footnotetext{
${ }^{9}$ It is not an accident that the BJP leader L.K. Advani, had chosen Somnath to begin his Rath Yatra procession- aimed at ethnic mobilization across the country- in 1990 (Blakeslee, 2013). Yet, records exist that in 1262, the authorities of the rebuilt Somnath temple made a large-scale land grant of temple lands to a Muslim trader, Nur-ud-din Firuz of Hormuz to settle in the adjacent medieval trading port of Veraval, aware of the commercial taxation and prosperity that a colony of Muslims could bring (Sircar, 1962, Thapar, 2004, Jha, forthcoming). This ethnically- mixed community still exists, despite Veraval's diminished economic prospects as a fishing port in a largely vegetarian state. Yet, Veraval too remained peaceful in 2002.

${ }^{10}$ Thus, when the Mughal Emperor Aurangzeb went South to campaign in the late 17th century, it was not unusual that four of five of Delhi's 400,000 residents left with him (Blake, 1991).

${ }^{11}$ The walled city of Delhi, Shahjahanabad, founded in 1638 as the capital of the Mughal empire, still appears to exhibit these features. In my fieldwork there, I found Muslims largely concentrated in separate mohallas near the Jama Masjid, the Fatehpuri Masjid and Ballimaran. Distinct styles of clothing, the focus of community common space around the mosque and stalls that advertise using Arabic script (Urdu) provide overt indicators of the ethnic composition of the mohalla. Similarly, in Ahmadabad, gated pols separated ethnic groups within the medieval core (Gillion, 1968, Jha, forthcoming). See also Noe (1993) on Delhi and Brass (2003)[p.150-160] on Aligarh.
} 
to Islam and enjoyed historical wealth, patronage centres were the historical focus of interethnic competition rather than inter-ethnic complementarity and exchange. Thus patronage centres were less likely to develop institutions to support to support such exchange, and instead were likely to continue to be loci for competition in economic spheres. ${ }^{12}$

Figure 6 shows those incomplete conquests that shape the local variation of Muslim rule within Gujarat. Despite Somnath being one of the first towns to be raided by Muslims in 1026, parts of Gujarat were bypassed by the great conquests of Muhammad Ghori and later by Ala-ud-din Khilji. Though the subsequent Tughlak sultanate of Delhi established control throughout the region, parts of Gujarat, particularly in Saurath, regained autonomy. The Sultanate of Gujarat, established by a rebel Tughlak governor in 1407 led to the founding of Ahmadabad as its capital and the consolidation of a powerful proto-state that continued until the reign of Mughal emperor Akbar. The broad variation in the timing of conquests tended to be very episodic- led by particular dynamic rulers like Ala-ud-din, and halting at his death and during times of struggle over dynastic succession. As Figure 6 suggests, barriers to cavalry- such as due to the river Tapti, or even small slopes, such as that near Rajkotplayed some role in generating local variation that had remarkably persistent effects on local political control historically, but arguably are less relevant to modern political mobilization.

\section{Data}

To construct the dataset for the analysis, I went through news reports on Gujarat from the day of the burning of the Sabarmati Express on February 27th until April 15th. News sources include rediff.com and the Times of India. These were supplemented from an amicus curiae brief by the Concerned Citizens Tribunal and a compilation of eyewitness refugee testimonial by the People's Union for Democratic Rights (2002), which provided information about lesswidely publicised violence in smaller towns and villages. Following Varshney and Wilkinson (2004), I coded a riot as occurring in a town if there was evidence of violence by communallyidentifiable "mobs" or other large groups in that town. I also coded a day of "violence" as having occurred in a town if there was an isolated incident, such as a stabbing, without any evidence of broader groups being involved.

Following Jha (2008, forthcoming) I identified a town as a medieval trading port if it exhibited substantive evidence of direct overseas trade, prior to the 18th century and independent of European involvement. This definition eliminates most river ports and those

\footnotetext{
${ }^{12}$ Consistent with this interpretation,Field, Levinson, Pande and Visaria (2008) find evidence that violence within the city of the Muslim capital of Ahmadabad occurred within the context of competition between the different ethnic groups over property.
} 


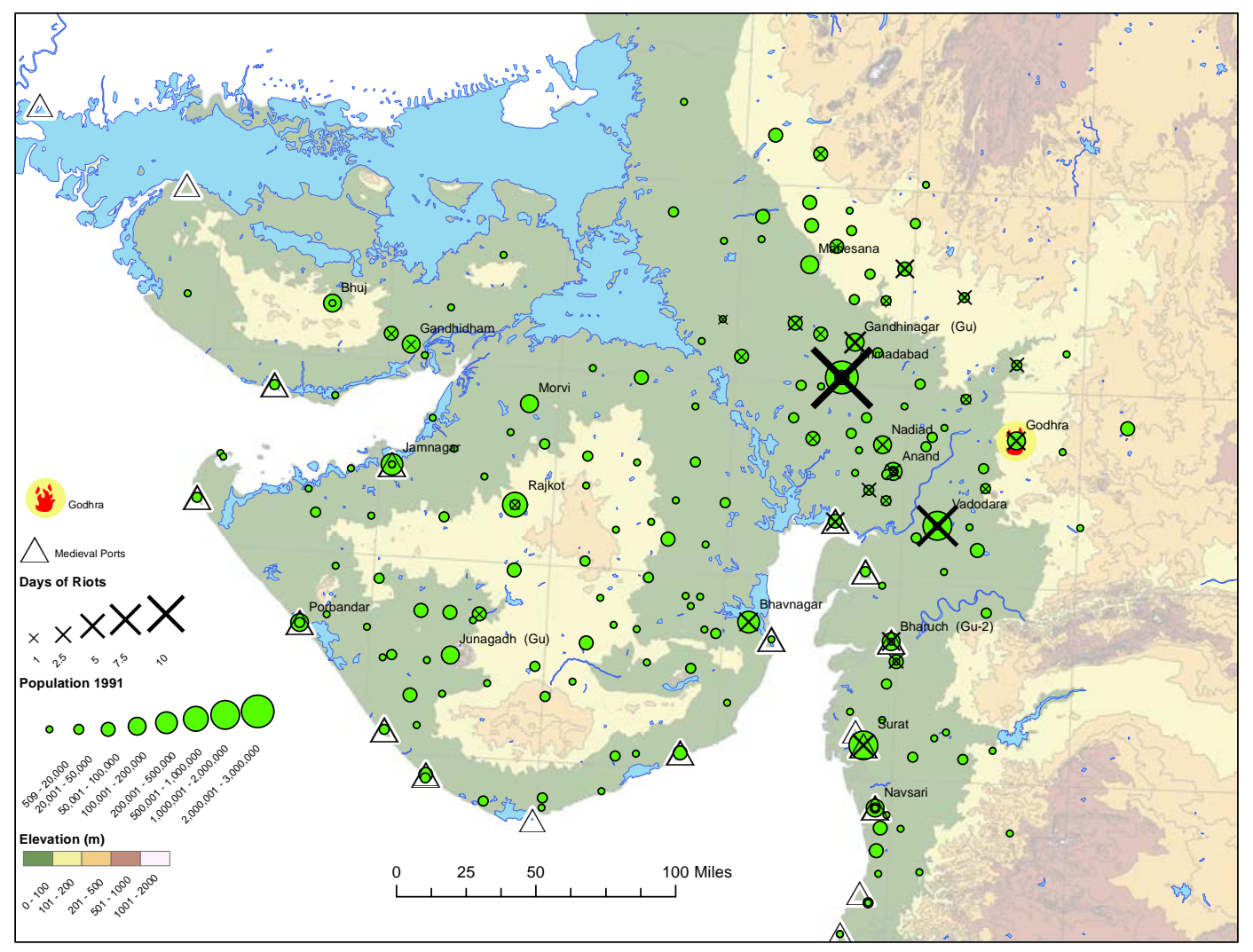

Figure 5: The Geography of medieval trade and Gujarat riots, Feb-April 2002

Gujarati medieval ports emerged at small indentations on the coast and near the mouths of the Tapti and Narmada. Out of sample medieval ports such as Diu and Daman (occupied by the Portuguese and now a separate state) and Thatta (in modern Pakistan) are provided for reference. Gujarat is mostly flat plains and marshland, with virtually all of its surface within 500 metres of sea level. 


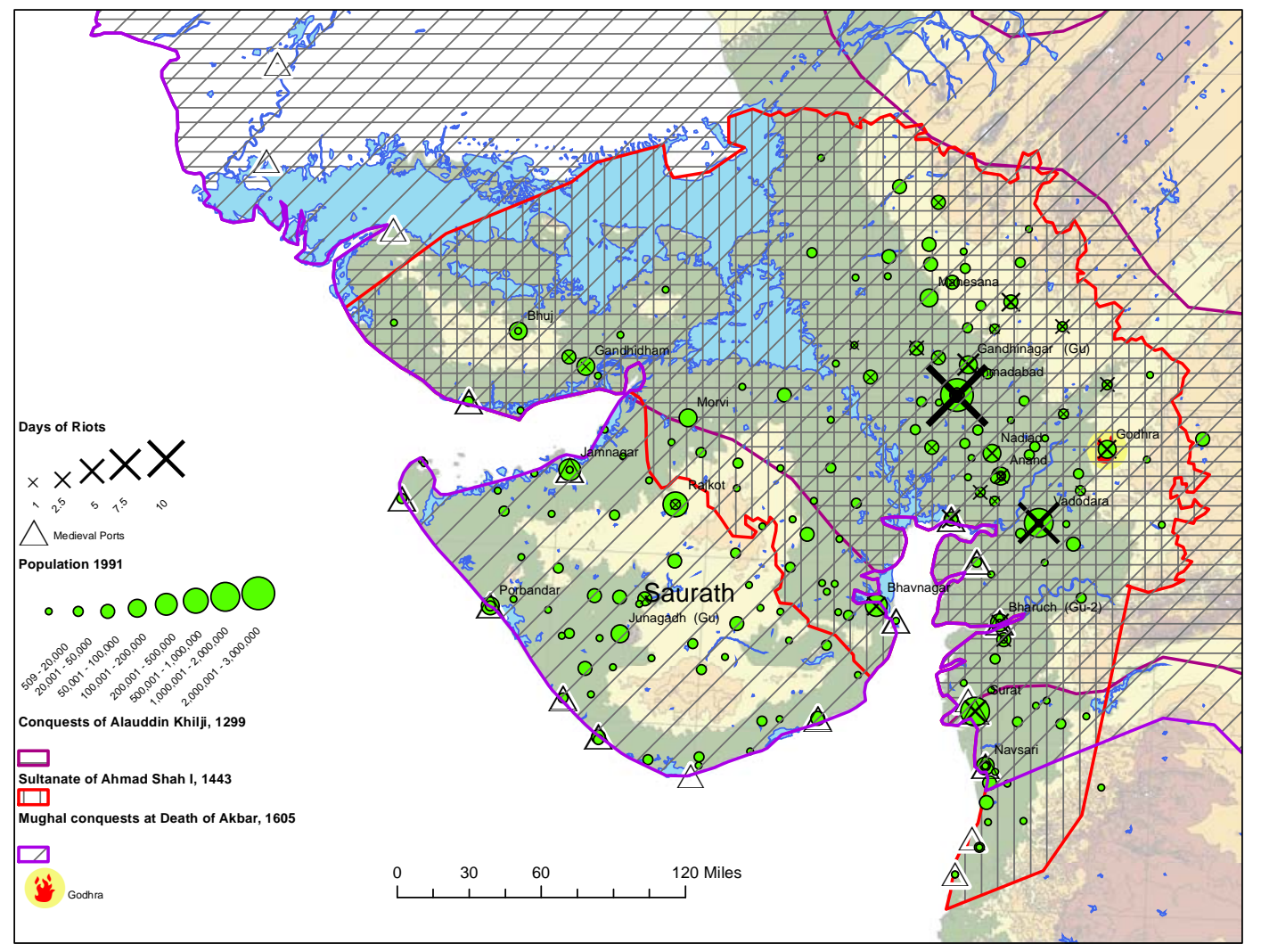

Figure 6: Dynasties and Local Variation in Muslim Political Rule in Gujarat

Locally, even small elevation changes (of $\leq 100 \mathrm{~m}$ ) and unbridged rivers such as the Tapti near Surat that were discontinuously challenging to Muslim cavalry could produce fairly persistent borders. 
ports founded by Europeans. Of the 68 confirmed medieval trading ports in undivided India, 13 are in our sample of Gujarati towns.

The Periplus Maris Erythraei (Casson, ed, 1989), an ancient Greek navigator's handbook (ca 1-4th century) provided the locations of a number of pre-Muslim and early Muslim ports which were then supplemented by moving forward in time, examining the records of contemporary Muslim, Christian and Chinese observers, including Chau Jukua (1225), Ibn Ibn Battuta (1355), Ludovico di Verthema (1503), Duarte Barbosa (1519) and Zayn al-Din al Malibari (1528). These contemporary accounts were augmented by secondary sources (Yule, ed, 1866, Subrahmanyam, 1990, Chaudhuri, 1995, Chakravarti, 2000). Finally, every town listed in the Imperial gazetteers of India from 1907 was examined for evidence of contemporary and medieval trade and to trace its foundation and historic role as an administrative, as well as a trade, center.

These medieval ports were linked to their geographical location using ArcGIS. To categorize medieval era "natural harbours," I used the US Geological Survey Digital Atlas of South Asia 2001 to identify water bodies that were within $10 \mathrm{~km}$ of the modern Indian coastline, including non-perennial ponds and streams and those without an outlet to the sea. If these water bodies intersected the coast in the medieval period, they would have produced minor inlets, or sheltered harbours. I define towns within $10 \mathrm{~km}$ of those water bodies as having had access to a "medieval natural harbour." This approach identifies major irregularities and inlets that are likely to have existed in the medieval period. Figure 5 reveals the location of these inlets and to the medieval ports that emerged.

Looking at effects over long periods of history raises a separate challenge that deviates from a canonical experiment: even controlling for initial conditions, towns under study were subject to differences in external political influences both during and after the treatment that might also influence subsequent religious relations. Some component of these political influences- e.g. the expansion of Muslim or European political rule- might have been in part a result of a desire to occupy regions with active medieval trade. To account for these political channels, I compare the effect of medieval trade both with and without a rich set of controls for these political factors, and assess sensitivity of our baseline estimates.

I also want to examine the effect of Muslim political rule. If,as I have argued, Muslim political rule is likely to have rendered intensified historic and persistent ethnic competition for patronage, then a greater exposure to Muslim political rule might be associated with a greater propensity for contemporary ethnic mobilization. The presence of state protectors of local minorities may also have crowded out mutual incentives to develop local institutions of trust in towns with inter-ethnic complementarity (Jha, forthcoming). However, it might also be that longer exposure to Muslim minority rulers has a beneficial effect by reducing 
psychological biases, as in Beaman, Chattopadhyay, Duflo, Pande and Topalova (2009). To derive such a local measure of the historic stock of Muslim political rule, I used historical maps of the extent of Muslim sultanates and empires over time, particularly drawing on Schmidt (1999) and the medieval chronicler Ferishta (1620). Layering these maps over time gives a measure of the duration every location was under Muslim rule prior to the death of the Emperor Aurangzeb in 1707 (see eg Figure 6). Since, our preferred estimation involves 1991 district level fixed effects, we will be exploiting this local variation of towns within the same district that acted as patronage centers due to their genesis as Muslim administrative cities, or had different extents of Muslim rule. ${ }^{13}$

After the death of Aurangzeb in 1707, the Mughal empire began to rapidly fall apart, leading to a period of rapidly changing borders between nascent proto-states before the expansion of British rule from 1757 onwards led to the consolidation of colonial districts and subsidiary native states. The British occupied some key commercial districts, like those of Ahmadabad and Surat, though Vadodara was left in Maratha hands. In Gujarat more generally, Muslim and Hindu native rulers were particularly important, with the Nawab of Junagadh and the Sultan of Cambay being prominent examples of the latter (see Appendix 7). We will also add separate controls for the religion of native rulers in the colonial period, relative to those districts- such as Ahmadabad, Broach, Panch Mahals and Surat- that were controlled directly by the British.

Another potential reason mooted for group cooperation (eg Wade, 1988) or conflict (eg Miguel, Satyanath and Sergenti, 2004) is the propensity for natural disasters that require people to work together or may lead to greater attempts to extract. Economic shocks due to rainfall (Bohlken and Sergenti, forthcoming), or relative income changes between Hindus and Muslims have also been suggested as potential precipitants of violence (Mitra and Ray, 2010), while economic shocks may also encourage the adoption of religious behaviours that provide entry into 'clubs' that provide social insurance (Chen, 2010). While the two month period of the ethnic riots in Gujarat did not exhibit much weather variation, long-term differences in propensities for such shocks might also be important. Thus I collected data from the Imperial gazetteers on a number of different natural disasters from 1850 to 1900, including droughts, earthquakes, locust infestations, floods and cyclones.

To examine the extent to which past ethnic cleansing may have also driven contemporary conflict, I use the Partition-era measure of 'minority outflows' developed by Bharadwaj, Khwaja and Mian (2008a). It is the reduction of the Muslim population relative to that

\footnotetext{
${ }^{13}$ It is likely, however, that Muslim conquerors- like those that resisted them- contested those with the highest wealth potential the most. Insofar as wealth decreases ethnic violence (eg Fearon and Laitin, 2003) this is likely to lead to downward bias on using these measures as a proxy for the historical legacy of inter-ethnic competition.
} 
expected given local trends in Muslim fertility and local mortality rates of those not targeted during the time of the Partition. As Jha and Wilkinson (2012) argue, this measure is arguably a good measure of ethnic cleansing, as it gauges how many members of the target ethnic minority departed, were removed, were forcibly converted as well as were killed during the Partition period.I also build on Bharadwaj et al. (2008a) to examine whether a key potential source of grievance- the extent to which a district or native state territorial unit ${ }^{14}$ received Hindu and Sikh refugees from Pakistan- also may have influenced the extent of contemporary Hindu-Muslim violence and political polarization. ${ }^{15}$

I merged the town data to the Electoral Commission's data on each Vidhan Sabha constituency using the spatial point location of the centre of the town. While some urban areas, particularly for the larger towns, such as Ahmadabad, Surat, Vadodara and Rajkot span multiple constituencies, the old precincts that are of particular interest largely correspond to the central constituencies. I supplement this electoral data with data on town-level religious composition from the 1981 Census and other town-level data on potential factors that might also influence political behaviour- such as worker participation rates, the caste composition and literacy rates- from the town directories of the 1991 Census.

Since I argue that medieval trade incentives due to the Hajj induced complementarity between Hindus and Muslims that later were undermined with increased European intervention, modern ports can act as a useful placebo comparison, one which also allows us to control for any modern port effects. For this reason, I also gathered data on contemporary port activity from the Gujarat Maritime Board.

\section{Results}

Table 1 provides summary statistics for our sample, by status as medieval port. Though they became significantly more competitive in the 2002 elections, medieval ports in Gujarat are not significantly different in the degree of competitiveness of the election in 1998 or in their histories of Muslim rule and partition-era migration.

There is also no a priori evidence that Gujarati medieval ports were more peaceful than other towns following the Godhra incident. In fact, $23 \%$ of Gujarati medieval ports experienced religious rioting, compared to $16 \%$ of other towns. However, Gujarati medieval

\footnotetext{
${ }^{14}$ Gujarat was divided into many territorial units prior to Independence, largely due to the many princely states. Thus data observed at the level of historical territorial units can create within-modern district variation that we will exploit.

${ }^{15}$ Fair, Malhotra and Shapiro (2013) use an endorsement list experiment to document a striking relationship in Pakistan between support for militant organizations and negative sentiment towards India's actions in Kashmir. It is interesting that those districts where such sentiments seem to be highest visually correspond to those areas that had the greatest influx of refugees from India during the Partition.
} 
Table 1: Summary statistics, Gujarat riots data, February-April 2002:

\begin{tabular}{|c|c|c|c|c|c|}
\hline & \multicolumn{2}{|c|}{$\begin{array}{l}\text { Other Gujarati } \\
\text { towns }(\mathrm{N}=167)\end{array}$} & \multicolumn{2}{|c|}{$\begin{array}{l}\text { Medieval Ports } \\
\qquad(\mathrm{N}=13)\end{array}$} & \multirow[t]{2}{*}{$\begin{array}{l}\text { 2-sided t } \\
\text { (Welch) }\end{array}$} \\
\hline & Mean & SD & Mean & SD & \\
\hline \multicolumn{6}{|l|}{ Electoral and Violence measures: } \\
\hline Religious riot occurred & 0.156 & 0.364 & 0.231 & 0.439 & \\
\hline Days of religious rioting & 0.455 & 2.153 & 0.769 & 1.481 & \\
\hline Religious violence occurred & 0.299 & 0.459 & 0.308 & 0.480 & \\
\hline Vote swing to BJP 1998-2002 & 3.328 & 12.523 & -0.706 & 10.807 & \\
\hline BJP vote share 2002 & 49.143 & 11.144 & 47.705 & 7.164 & \\
\hline BJP vote share 1998 & 45.815 & 10.902 & 48.411 & 12.451 & \\
\hline Winner: Runner Up Vote Ratio 2002 & 1.458 & 0.445 & 1.245 & 0.275 & $* *$ \\
\hline Winner: Runner Up Vote Ratio 1998 & 1.512 & 0.478 & 1.736 & 0.710 & \\
\hline \multicolumn{6}{|l|}{ Distance to Godhra measures: } \\
\hline Within $100 \mathrm{~km}$ of Godhra & 0.168 & 0.375 & 0.000 & 0.000 & $* * *$ \\
\hline Within $200 \mathrm{~km}$ of Godhra & 0.407 & 0.493 & 0.308 & 0.480 & \\
\hline Within $300 \mathrm{~km}$ of Godhra & 0.623 & 0.486 & 0.385 & 0.506 & \\
\hline \multicolumn{6}{|l|}{ Geographical initial conditions: } \\
\hline Town with Medieval Natural Harbour & 0.168 & 0.375 & 0.769 & 0.439 & $* * *$ \\
\hline Coastal town & 0.162 & 0.369 & 1.000 & 0.000 & $* * *$ \\
\hline Log (Dist. to Navigable River) & 13.022 & 0.273 & 12.964 & 0.372 & \\
\hline Natural disasters, 1850-1900 & 2.060 & 2.203 & 1.308 & 2.250 & \\
\hline \multicolumn{6}{|l|}{ Historical measures: } \\
\hline Town Muslim- founded or Muslim capital & 0.012 & 0.109 & 0.154 & 0.376 & \\
\hline Centuries Muslim Rule & 3.465 & 1.020 & 2.998 & 1.176 & \\
\hline Town under Hindu ruler & 0.635 & 0.483 & 0.462 & 0.519 & \\
\hline Town under Muslim ruler & 0.084 & 0.278 & 0.231 & 0.439 & \\
\hline \% Hindu / Sikh Partition Inflows 1931-51 & 1.150 & 1.031 & 1.160 & 1.017 & \\
\hline \% Muslim Outflows 1931-51 & 1.486 & 1.818 & 2.462 & 2.512 & \\
\hline \multicolumn{6}{|l|}{ Demographic measures: } \\
\hline Log(population 1991) & 10.156 & 0.989 & 11.342 & 1.267 & $* * *$ \\
\hline Class 1 Town $(100,000+)$ & 0.078 & 0.269 & 0.385 & 0.506 & $*$ \\
\hline Class 2 Town $(50-100,000)$ & 0.162 & 0.369 & 0.231 & 0.439 & \\
\hline Class 3 Town $(25-50,000)$ & 0.287 & 0.454 & 0.308 & 0.480 & \\
\hline Proportion Muslim & 17.283 & 0.130 & 24.534 & 0.142 & $*$ \\
\hline Prop. Scheduled Tribe in Town & 4.936 & 8.736 & 3.433 & 5.412 & \\
\hline Prop. Scheduled Caste in Town & 7.521 & 3.813 & 5.763 & 1.701 & $* * *$ \\
\hline \multicolumn{6}{|l|}{ Economic measures: } \\
\hline Active port in 2001 & 0.072 & 0.259 & 0.692 & 0.480 & $* * *$ \\
\hline Worker's participation rate & 30.142 & 7.475 & 29.001 & 2.272 & \\
\hline Literacy rate & 72.887 & 9.570 & 71.670 & 6.365 & \\
\hline
\end{tabular}

All measures based upon 1991 values unless otherwise mentioned. Welch t-test allows unequal variances; ${ }^{*}$ significant at $10 \% ; * * 5 \% ; * * * 1 \%$ 
trading ports are significantly larger, and have, on average, a larger proportion of Muslims than the average Gujarati town (24\% compared to $17.3 \%$ ). Gujarati medieval ports tended to be outside the $100 \mathrm{~km}$ radius of Godhra where the earliest violence occurred. We will control for both population size and distance to Godhra in all subsequent regressions, as well as focusing our attention specifically on local within-district variation.

\section{Table 2: Regression: Determinants of Medieval Port Location}

\begin{tabular}{lcccccc}
\hline & $(1)$ & $(2)$ & $(3)$ & $(4)$ & $(5)$ & $(6)$ \\
Town at Medieval Natural Harbour & $0.067^{*}$ & $0.058^{*}$ & $0.061^{*}$ & $0.063^{*}$ & $0.057^{*}$ & $0.062^{* *}$ \\
& {$[0.035]$} & {$[0.032]$} & {$[0.031]$} & {$[0.033]$} & {$[0.030]$} & {$[0.027]$} \\
& $0.275^{* * *}$ & $0.269^{* * *}$ & $0.276^{* * *}$ & $0.342^{* * *}$ & $0.319^{* * *}$ & $0.314^{* * *}$ \\
Coastal town & {$[0.084]$} & {$[0.084]$} & {$[0.079]$} & {$[0.080]$} & {$[0.085]$} & {$[0.086]$} \\
& -0.049 & -0.041 & -0.027 & $-0.316^{* *}$ & $-0.369^{* * *}$ & $-0.413^{* *}$ \\
Log (Dist. to Navigable River) & {$[0.068]$} & {$[0.055]$} & {$[0.050]$} & {$[0.123]$} & {$[0.105]$} & {$[0.143]$} \\
& 0.005 & 0.006 & 0.011 & -0.010 & -0.005 & -0.004 \\
Natural disasters, 1850-1900 & {$[0.006]$} & {$[0.008]$} & {$[0.008]$} & {$[0.011]$} & {$[0.006]$} & {$[0.005]$} \\
& & $0.349^{*}$ & $0.326^{*}$ & & $0.375^{*}$ & $0.358^{*}$ \\
Town Muslim- Founded or Capital & & {$[0.189]$} & {$[0.183]$} & & {$[0.198]$} & {$[0.203]$} \\
& & -0.003 & 0.001 & & -0.021 & -0.023 \\
Centuries Muslim Rule (to 1707) & & {$[0.014]$} & {$[0.012]$} & & {$[0.013]$} & {$[0.013]$} \\
& & & 0.034 & & & -0.008 \\
Town under Hindu Ruler (to 1947) & & & {$[0.031]$} & & & {$[0.018]$} \\
& & & $0.089 * *$ & & & 0.060 \\
Town under Muslim Ruler (to 1947) & & & {$[0.042]$} & & & {$[0.048]$} \\
\hline District Fixed Effects & $\mathrm{N}$ & $\mathrm{N}$ & $\mathrm{N}$ & $\mathrm{Y}$ & $\mathrm{Y}$ & $\mathrm{Y}$ \\
Observations & 182 & 182 & 182 & 182 & 182 & 182 \\
R-squared & 0.27 & 0.31 & 0.31 & 0.34 & 0.38 & 0.38 \\
\hline \hline
\end{tabular}

Notes: Robust standard errors (clustered at 1991 district level): ${ }^{*}$ significant at $10 \%$; ${ }^{* *} 5 \% ; * * * 1 \%$

Table 2 shows the determinants of medieval port location, as a function of geographical characteristics ( $\mathrm{Col} \mathrm{1)}$, and sequentially adding measures of medieval ( $\mathrm{Col} \mathrm{2)}$ and colonial exposure (Col 3) to Muslim or Hindu patronage and political power (relative to British rule), and then making these comparisons to other towns within the same district (Cols 4-6). Notice that across specifications, a key determinant of Gujarati medieval port location is that they are more likely to be coastal towns located at medieval natural harbours. Controlling for evidence of any shipping activity in our preferred regressions, which we will also show to be unrelated to contemporary violence and voting behaviour, our identification rests on the assumption that since medieval ports were selected to be at small indentations on the medieval coast, that relative to towns close by , such selection has little effect on contemporary violence. ${ }^{16}$

\footnotetext{
${ }^{16}$ As mentioned above, we also control for natural disasters which could be mitigated in historically sheltered harbours, though Table 2 shows no such relationship. Jha (forthcoming) has sufficient power to use the medieval natural harbour variation explicitly as an instrument in the sub-continental sample, and finds very consistent results with the OLS estimation, which we will focus upon exclusively in this exercise.
} 
Within Gujarat, medieval ports also appear somewhat likely to have been founded or used as administrative capitals by Muslims- which we can show leads to greater BJP support in 2002, not less- and in the within-district comparison, appear to be located closer to navigable rivers. We will control for these factors explicitly. ${ }^{17}$ Otherwise medieval ports seem very similar in their political histories to other towns, both across the state and compared to towns within the same district.

Table 3 examines which towns had close races in the pre-pogrom 1998 elections, as measured by the vote share ratio of the winning party to the runner-up. Notice that, comparing towns with similar geographical characteristics, size and proximity to Godhra (Col 1), medieval and colonial patterns of political rule ( $\mathrm{Col} 2)$, and Partition-era and contemporaneous economic characteristics ( $\mathrm{Col} 3$ ), and comparing such towns within districts (Cols 4-6), the major determinant of competitiveness in the 1998 elections were the duration of Muslim rule or whether a town had once been a Muslim capital or patronage centre. Medieval ports were not any more or less competitive in the 1998 elections.

Table 4(Cols 1-6) uses the same comparisons to examine the determinants of the lognormalized number of days of rioting during February-April 2002. Notice first that comparing both between and within districts, medieval ports experienced $25 \%$ fewer days of rioting in that period. This effect strengthens with the addition of controls and comparing towns within the same district. Further, Table 4(Col 7-9) reveals, consistent with Wilkinson and Haid (2009), that the closer the 1998 election-i.e. the lower the vote ratio between winner and runner-up - the greater the days of rioting. However, the coefficient on the interaction between medieval port and the vote ratio is positive: medieval ports are likely to have a greater effect at reducing the days of rioting when they had previously faced greater electoral competition. Thus local institutions of inter-ethnic tolerance appear to be most effective when the incentive for violence may have been greatest. ${ }^{18}$

We may be concerned that though the (log. normalised) number of days of rioting in

\footnotetext{
${ }^{17}$ The correlation with proximity to navigable rivers within districts may suggest that medieval ports may now be richer for this reason. Yet, as we shall show, controlling for the presence of any shipping activity in the port does not appear to affect the results, and controlling for town municipal income and expenditures do not effect the results [results not shown]. Further Jha (forthcoming) uses household data from the Indian Human Development Survey to show that across the country in 2005, while urban households in districts with medieval port headquarters are not wealthier on average, Muslims in medieval ports do appear to be less poor than Hindus. According to Mitra and Ray (2010) such rises in minority wealth should give rise to greater violence, not less.

${ }^{18}$ Other factors that explain variation in the days of rioting among towns across districts are the length of Muslim rule, one century of which raises the number of days of rioting by $9 \%$, the proportion of Muslims (that raises the incidence of violence) and of scheduled tribes (that reduces it). Looking within towns of the same district with similar levels of contemporary Muslim population, there is some evidence that greater Partition-era ethnic cleansing, as measured by minority outflows, also reduces contemporary rioting. This may reflect the increase in dissimilarity in employment between Hindus and Muslims that resulted from the Partition (Bharadwaj, Khwaja and Mian, 2008b).
} 
Table 3: Regression: Winner-Runner Up Vote Share Ratio, 1998 Vidhan Sabha Elections:

\begin{tabular}{|c|c|c|c|c|c|c|}
\hline & (1) & (2) & (3) & (4) & (5) & (6) \\
\hline \multirow[t]{2}{*}{ Medieval Port } & 0.152 & 0.203 & 0.132 & 0.056 & 0.096 & 0.066 \\
\hline & {$[0.151]$} & {$[0.170]$} & {$[0.202]$} & [0.183] & {$[0.200]$} & {$[0.220]$} \\
\hline \multirow[t]{2}{*}{ Town Muslim- founded or capital } & & $-0.740 * * *$ & $-0.651 * *$ & & $-0.685^{* *}$ & $-0.663^{* *}$ \\
\hline & & {$[0.216]$} & {$[0.254]$} & & {$[0.253]$} & {$[0.291]$} \\
\hline \multirow[t]{2}{*}{ Centuries Muslim Rule (to 1707) } & & $-0.154 * * *$ & $-0.135 * * *$ & & $-0.334 * * *$ & $-0.323 * * *$ \\
\hline & & {$[0.044]$} & {$[0.046]$} & & {$[0.056]$} & {$[0.059]$} \\
\hline \multirow[t]{2}{*}{ Town under colonial Hindu ruler } & & -0.089 & $-0.126 * *$ & & $-0.149 * *$ & -0.134 \\
\hline & & {$[0.072]$} & {$[0.058]$} & & {$[0.070]$} & {$[0.081]$} \\
\hline \multirow[t]{2}{*}{ Town under colonial Muslim ruler } & & 0.128 & -0.019 & & 0.013 & -0.056 \\
\hline & & {$[0.110]$} & {$[0.140]$} & & {$[0.070]$} & {$[0.168]$} \\
\hline \multirow{2}{*}{\multicolumn{2}{|c|}{ \% Partition Majority Inflows (1931-1951) }} & & -0.015 & & & 0.015 \\
\hline & & & {$[0.023]$} & & & [0.043] \\
\hline \multirow{2}{*}{\multicolumn{2}{|c|}{ \% Partition Muslim Outflows (1931-1951) }} & & 0.035 & & & 0.099 \\
\hline & & & [0.023] & & & {$[0.096]$} \\
\hline \multirow[t]{2}{*}{ Prop. Scheduled Tribe in Town } & & & -0.005 & & & -0.005 \\
\hline & & & [0.003] & & & {$[0.004]$} \\
\hline \multirow[t]{2}{*}{ Prop. Scheduled Caste in Town } & & & -0.004 & & & 0.002 \\
\hline & & & {$[0.010]$} & & & [0.013] \\
\hline \multirow[t]{2}{*}{ Active port in 2001} & & & 0.028 & & & 0.048 \\
\hline & & & [0.189] & & & [0.189] \\
\hline \multirow[t]{2}{*}{ Workers Participation Rate } & & & -0.003 & & & -0.003 \\
\hline & & & [0.002] & & & [0.002] \\
\hline \multirow[t]{2}{*}{ Literacy Rate } & & & 0.001 & & & 0.002 \\
\hline & & & {$[0.006]$} & & & [0.005] \\
\hline \multirow[t]{2}{*}{ Prop. Muslim in Town, 1981} & & & 0.433 & & & -0.221 \\
\hline & & & [0.845] & & & [0.951] \\
\hline \multirow[t]{2}{*}{ Prop. Muslim in Town ${ }^{2}, 1981$} & & & -0.904 & & & -0.057 \\
\hline & & & [1.298] & & & [1.269] \\
\hline District Fixed Effects & $\mathrm{N}$ & $\mathrm{N}$ & $\mathrm{N}$ & $\bar{Y}$ & $\mathrm{Y}$ & $\mathrm{Y}$ \\
\hline Observations & 180 & 180 & 180 & 180 & 180 & 180 \\
\hline R-squared & 0.12 & 0.22 & 0.24 & 0.24 & 0.33 & 0.35 \\
\hline
\end{tabular}

Notes: All regressions include log. distances from navigable rivers, coastal town, Natural Disasters, log. population (1991), Class of town (I,II,III), distance to Godhra (100,200,300km) and, where noted, 1991 district fixed effects. Historical controls include: Centuries Muslim rule, Muslimfounded or capital, \% Partition Hindu/ Sikh Inflows and Muslim Outflows. Contemporaneous controls include: Proportion SC/ST, Modern active port, Literacy Rate, Worker's Participation Rate, Proportion Muslim 1981 (and a quadratic term). All values observed in 1991 unless noted. Robust standard errors in brackets (clustered at 1991 district): * significant at 10\%; ** 5\%; *** $1 \%$ 


\section{Table 4: Regression (OLS): Log Riot Days, February-April 2002:}

\begin{tabular}{|c|c|c|c|c|c|c|c|c|c|}
\hline & (1) & (2) & (3) & (4) & (5) & (6) & (7) & (8) & (9) \\
\hline \multirow[t]{2}{*}{ Medieval Port } & -0.188 & $-0.253 * *$ & $-0.313^{* *}$ & $-0.256^{* *}$ & $-0.311 * *$ & $-0.337 * * *$ & $-0.594 * *$ & $-0.948 * * *$ & $-0.772 * * *$ \\
\hline & {$[0.134]$} & [0.108] & {$[0.118]$} & {$[0.099]$} & {$[0.114]$} & {$[0.108]$} & {$[0.264]$} & [0.255] & {$[0.231]$} \\
\hline \multirow[t]{2}{*}{ Medieval Port x Votes Ratio 1998} & & & & & & & 0.207 & $0.379 * *$ & $0.258^{*}$ \\
\hline & & & & & & & [0.158] & {$[0.144]$} & {$[0.147]$} \\
\hline \multirow{2}{*}{\multicolumn{2}{|c|}{ Votes Ratio: Winner to Runner-Up, 1998}} & & & & & & $-0.100 * *$ & $-0.093^{*}$ & -0.076 \\
\hline & & & & & & & {$[0.046]$} & {$[0.051]$} & {$[0.058]$} \\
\hline \multirow{2}{*}{\multicolumn{2}{|c|}{ Town Muslim- founded or capital }} & 0.603 & 0.558 & & 0.463 & 0.484 & & 0.545 & 0.542 \\
\hline & & {$[0.468]$} & [0.452] & & {$[0.494]$} & [0.455] & & [0.492] & [0.472] \\
\hline \multirow{2}{*}{\multicolumn{2}{|c|}{ Centuries Muslim Rule (to 1707) }} & 0.047 & $0.091^{* *}$ & & 0.013 & 0.021 & & -0.014 & -0.004 \\
\hline & & [0.033] & {$[0.040]$} & & {$[0.074]$} & {$[0.068]$} & & {$[0.086]$} & {$[0.078]$} \\
\hline \multirow{2}{*}{\multicolumn{2}{|c|}{ Town under colonial Hindu ruler }} & 0.058 & 0.046 & & 0.074 & 0.152 & & 0.081 & 0.14 \\
\hline & & {$[0.081]$} & {$[0.102]$} & & {$[0.098]$} & {$[0.103]$} & & {$[0.088]$} & {$[0.104]$} \\
\hline \multirow{2}{*}{\multicolumn{2}{|c|}{ Town under colonial Muslim ruler }} & 0.07 & 0.038 & & 0.205 & 0.245 & & 0.289 & 0.279 \\
\hline & & [0.132] & [0.187] & & {$[0.200]$} & {$[0.170]$} & & [0.198] & [0.180] \\
\hline \multirow{2}{*}{\multicolumn{2}{|c|}{ \% Partition Majority Inflows (1931-1951) }} & & -0.002 & & & 0.028 & & & 0.018 \\
\hline & & & {$[0.034]$} & & & {$[0.028]$} & & & {$[0.028]$} \\
\hline \multirow{2}{*}{\multicolumn{2}{|c|}{ \% Partition Muslim Outflows (1931-1951) }} & & -0.015 & & & $-0.063^{*}$ & & & -0.05 \\
\hline & & & {$[0.019]$} & & & {$[0.033]$} & & & {$[0.037]$} \\
\hline \multirow[t]{2}{*}{ Prop. Scheduled Tribe in Town } & & & $-0.013^{* * *}$ & & & $-0.019 * *$ & & & $-0.019 * *$ \\
\hline & & & [0.004] & & & {$[0.007]$} & & & {$[0.008]$} \\
\hline \multirow[t]{2}{*}{ Prop. Scheduled Caste in Town } & & & 0.001 & & & 0.001 & & & 0.002 \\
\hline & & & {$[0.008]$} & & & {$[0.008]$} & & & {$[0.008]$} \\
\hline \multirow[t]{2}{*}{ Active port in 2001} & & & 0.156 & & & 0.173 & & & 0.166 \\
\hline & & & {$[0.141]$} & & & {$[0.170]$} & & & [0.164] \\
\hline \multirow[t]{2}{*}{ Workers Participation Rate } & & & 0.004 & & & 0.004 & & & 0.004 \\
\hline & & & {$[0.007]$} & & & {$[0.006]$} & & & {$[0.006]$} \\
\hline \multirow[t]{2}{*}{ Literacy Rate } & & & -0.002 & & & -0.006 & & & -0.005 \\
\hline & & & [0.004] & & & [0.004] & & & {$[0.004]$} \\
\hline \multirow[t]{2}{*}{ Prop. Muslim in Town, 1981} & & & $1.099 * *$ & & & $0.809 *$ & & & $0.777^{*}$ \\
\hline & & & {$[0.475]$} & & & {$[0.443]$} & & & {$[0.438]$} \\
\hline \multirow[t]{2}{*}{ Prop. Muslim in Town ${ }^{2}, 1981$} & & & $-1.247^{*}$ & & & $-1.189 *$ & & & -1.088 \\
\hline & & & [0.599] & & & {$[0.629]$} & & & [0.642] \\
\hline \multicolumn{2}{|l|}{$\begin{array}{l}\text { Joint-F Med Port vars. } \\
\text {. }\end{array}$} & & & & & & 5.05 & 9.34 & 10.68 \\
\hline \multicolumn{2}{|l|}{ Prob $>\mathrm{F}$} & & & & & & 0.02 & 0.00 & 0.00 \\
\hline District Fixed Effects & $\mathrm{N}$ & $\mathrm{N}$ & $\mathrm{N}$ & $\bar{Y}$ & $\bar{Y}$ & $\bar{Y}$ & $\bar{Y}$ & $\bar{Y}$ & $\bar{Y}$ \\
\hline Observations & 182 & 182 & 182 & 182 & 182 & 182 & 180 & 180 & 180 \\
\hline R-squared & 0.49 & 0.52 & 0.57 & 0.59 & 0.61 & 0.65 & 0.6 & 0.62 & 0.66 \\
\hline
\end{tabular}

Notes: All regressions include log. distances from navigable rivers, coastal town, Natural Disasters, log. population (1991), Class of town (I,II,III), distance to Godhra (100,200,300km) and, where noted, 1991 district fixed effects. Historical controls include: Centuries Muslim rule, Muslimfounded or capital, \% Partition Hindu/ Sikh Inflows and Muslim Outflows. Contemporaneous controls include: Proportion SC/ST, Modern active port, Literacy Rate, Worker's Participation Rate, Proportion Muslim 1981 (and a quadratic term). All values observed in 1991 unless noted. Robust standard errors in brackets (clustered at 1991 district): * significant at 10\%; ** 5\%; *** $1 \%$ 
Table 5: Regression (OLS): Probability of a riot, February-April 2002

\begin{tabular}{|c|c|c|c|c|c|c|c|c|c|}
\hline & (1) & (2) & (3) & (4) & (5) & (6) & (7) & (8) & (9) \\
\hline \multirow[t]{2}{*}{ Medieval Port } & $-0.148 * *$ & $-0.180 * * *$ & $-0.205^{* * *}$ & $-0.175^{* * *}$ & $-0.202 * * *$ & $-0.200 * * *$ & $-0.416^{*}$ & $-0.642 * * *$ & $-0.522 * *$ \\
\hline & {$[0.068]$} & {$[0.055]$} & [0.069] & [0.047] & {$[0.056]$} & [0.067] & {$[0.228]$} & {$[0.191]$} & [0.223] \\
\hline \multirow{2}{*}{\multicolumn{7}{|c|}{ Medieval Port x Votes Ratio 1998}} & 0.147 & $0.260^{* *}$ & 0.19 \\
\hline & & & & & & & [0.137] & {$[0.113]$} & [0.138] \\
\hline \multirow{2}{*}{\multicolumn{7}{|c|}{ Votes Ratio: Winner to Runner-Up, 1998}} & -0.019 & -0.03 & -0.018 \\
\hline & & & & & & & {$[0.056]$} & [0.063] & {$[0.071]$} \\
\hline \multicolumn{7}{|c|}{ Joint-F Med Port vars. } & 10.44 & 15.13 & 7.48 \\
\hline \multicolumn{7}{|c|}{ Prob $>F$} & 0.00 & 0.00 & 0.00 \\
\hline District FE & $\mathrm{N}$ & $\mathrm{N}$ & $\mathrm{N}$ & $\bar{Y}$ & $\bar{Y}$ & $\mathrm{Y}$ & $\mathrm{Y}$ & $\bar{Y}$ & $\bar{Y}$ \\
\hline Observations & 182 & 182 & 182 & 182 & 182 & 182 & 180 & 180 & 180 \\
\hline R-squared & 0.36 & 0.38 & 0.42 & 0.46 & 0.47 & 0.5 & 0.46 & 0.48 & 0.51 \\
\hline
\end{tabular}

Notes: All regressions include log. distances from navigable rivers, coastal town, Natural Disasters, log. population (1991), Class of town (I,II,III), distance to Godhra $(100,200,300 \mathrm{~km})$ and, where noted, 1991 district fixed effects. Historical controls include: Centuries Muslim rule, Muslimfounded or capital, \% Partition Hindu/ Sikh Inflows and Muslim Outflows. Contemporaneous controls include: Proportion SC/ST, Modern active port, Literacy Rate, Worker's Participation Rate, Proportion Muslim 1981 (and a quadratic term). All values observed in 1991 unless noted. Robust standard errors in brackets (clustered at 1991 district): * significant at 10\%; ** 5\%; *** $1 \%$

the two month period captures relative intensity of ethnic rioting in a relatively accurately observable manner, such measures may still be susceptible to over-influence by outliers. Table 5 examines the extensive margin- whether any riot occurs in a town during this period. Notice that a medieval trade legacy reduces the probability of a riot occurring by around 20 percentage points. As above, these effects are amplified in medieval ports that faced strong electoral competition in 1998 (Cols 7-9).

Another possibility is that medieval ports simply have less violent individuals, regardless of community-level institutions or ethnic complementarity. Table 6 presents the coefficient on medieval port whether the town experienced any religious violence (both riots and isolated incidents of stabbings etc.) during the two months of the Godhra riots. Notice that despite having a strong effect on riots, medieval trading ports appear to have a weaker effect on whether violent incidents occur at all. Rather the major effect of a medieval trade legacy appears to be to reduce the escalation of religious violence into broader mob confrontation. This is consistent with the presence of community-level incentives provided by institutional mechanisms that mitigate shocks to inter-ethnic peace, rather than the presence of inherently peaceful individuals in medieval ports.

Table 7 examines the determinants of the vote share change of the ruling party, the BJP, before and after the riots. Notice that despite an average increase of 4.84 percentage points across the state in BJP support following the violence, medieval ports swung between 4.31 
Table 6: Regression: Any Violence, (including isolated incidents), Feb-April 2002

\begin{tabular}{lcccccc}
\hline & $(1)$ & $(2)$ & $(3)$ & $(4)$ & $(5)$ & $(6)$ \\
Medieval Port & -0.024 & -0.030 & -0.108 & -0.078 & -0.121 & -0.026 \\
& {$[0.148]$} & {$[0.120]$} & {$[0.097]$} & {$[0.082]$} & {$[0.211]$} & {$[0.198]$} \\
Votes Ratio: Winner to Runner-Up, 1998 & & & & 0.114 & 0.103 \\
& & & & & {$[0.067]$} & {$[0.069]$} \\
Medieval Port x Votes Ratio 1998 & & & & 0.005 & -0.031 \\
& & & & & {$[0.124]$} & {$[0.121]$} \\
\hline Joint-F Med Port vars. & & & & & 0.96 & 0.63 \\
Prob>F & $\mathrm{N}$ & $\mathrm{N}$ & $\mathrm{Y}$ & $\mathrm{Y}$ & $\mathrm{Y}$ & $\mathrm{Y}$ \\
District FE & 182 & 182 & 182 & 182 & 180 & 180 \\
Observations & 0.39 & 0.47 & 0.62 & 0.65 & 0.63 & 0.66 \\
R-squared & & & & & & \\
\hline \hline
\end{tabular}

Notes: All regressions include log. distances from navigable rivers, coastal town, Natural Disasters, log. population (1991), Class of town (I,II,III), distance to Godhra $(100,200,300 \mathrm{~km})$ and, where noted, 1991 district fixed effects. Historical controls include: Centuries Muslim rule, Muslimfounded or capital, \% Partition Hindu/ Sikh Inflows and Muslim Outflows. Contemporaneous controls include: Proportion SC/ST, Modern active port, Literacy Rate, Worker's Participation Rate, Proportion Muslim 1981 (and a quadratic term). All values observed in 1991 unless noted. Robust standard errors in brackets (clustered at 1991 district): * significant at 10\%; ** 5\%; *** $1 \%$

and 6.77 percentage points against the BJP in the aftermath of the riots, comparing towns within the same district ( $\mathrm{Col} 3-4)$. Towns within the same district that were exposed to greater spells of Muslim rule also appear to have swung towards the BJP following the violence, consistent with the interpretation that rather than reducing biases, such rule may have generated greater inter-ethnic competition. Columns 5-6 examine the differential effects of 1998 electoral competition. Notice that in other towns, those with lower vote ratios between winners and runners up in 1998- i.e. greater electoral competition-show higher gains in the BJP vote share. This is consistent with the notion that in non-medieval port towns, riots were efficiently-targeted from an electoral perspective. As the table reveals, the preferences of voters in non-medieval port marginal constituencies in 1998, which as we have seen were more likely to be in locations of historic ethnic- competition (Table 3), and were most severely affected by the ethnic rioting (Table 4), also became more aligned with the ruling party in its aftermath. In contrast, just as electorally competitive constituencies that were medieval ports were relatively less likely to experience ethnic rioting, electorally-competitive medieval port towns actually reveal a jointly-significant greater vote swing against the ruling party. As Table 7(Cols 7-8) reveal, the BJP appears to have lost vote share in non-port towns where it had the greatest (and thus inframarginal) support. These results are consistent with the targeted nature of riots as a strategy to attract votes in marginal constituencies that would respond well to such violence, rather than one that was generally popular throughout the 
state.

Note also that, unlike other towns, where the BJP vote share appears to have converged, in medieval ports, there is instead a polarizing effect of riots- those towns where the BJP did best were towns where it already had existing support, and it did worse in those towns where it had lower initial shares. These findings may be due to the influx of refugees from the violence in other parts of the state to 'safer' medieval ports due to their reputations as "oases of peace". 19

Table 8 examines the probability of a BJP seat win in the post-pogrom elections of 2002, and provides reinforcing evidence of the notion of riots as successfully targeted electoral strategy. Though the 1998 BJP vote share is negatively correlated with the swing in its 2002 vote share, it is positively correlated with the probability of winning a seat in 2002. Thus the BJP was able to gain vote share in the aftermath of the riots in those places that were electorally relevant. It did particularly well in places with histories of Muslim patronage. However, compared to other towns, medieval ports show a reduced probability of BJP success.

Table 9 examines the determinants of electoral competition in the aftermath of the riots in 2002 (Cols 1-4) and in the subsequent elections 5 years later (Cols 5-8). Notice first that towns with longer durations of Muslim rule, which had previously been significantly more competitive in 1998 had higher winner to loser vote shares following the 2002 violence, increasing the likelihood that they went from competitive to inframarginal seats. In contrast, a medieval trade legacy had become a key determinant of electoral competition, particularly in ports which had provided the BJP with lower vote shares in 1998. In fact, medieval ports continued to act as venues for heightened electoral competition in the 2007 elections as well (Cols 5-8). In fact, the location of marginal constituencies appear to have become more predictable more generally: contrary to a historical pattern where the vote share ratio of winners to runners up in Gujarati towns have tended to have correlation coefficients between adjacent election years of less than 0.2 , the post-pogrom patterns are close to double that (Table 10).

\footnotetext{
${ }^{19}$ The latter term was used to describe Surat during the Gujarat riots of 2002 by a Times of India editorial, Feb. 1, 2007. At the same time, there have may also have been an element of retrospective sanctioning of the ruling party. In Porbandar, I interviewed several Muslim members of the BJP minority wing, which also maintained an active role in several other medieval port towns. Donations to the BJP from minority groups were reportedly high prior to the violence as well, but lowered afterwards. The 2012 religion census has yet to be released but may allow us future research to unpack this further.
} 
Table 7: Regression: Ruling Party (BJP) Vote Change, 1998- 2002

\begin{tabular}{|c|c|c|c|c|c|c|c|c|}
\hline & $(1)$ & (2) & (3) & (4) & (5) & (6) & (7) & (8) \\
\hline \multirow[t]{2}{*}{ Medieval Port } & -1.665 & $-5.157 * *$ & $-4.317 * * *$ & $-6.773 * *$ & -8.033 & -10.746 & $-11.686 *$ & $-17.283 * *$ \\
\hline & [2.745] & [2.383] & [1.357] & [2.702] & {$[6.500]$} & [7.221] & [5.919] & {$[6.843]$} \\
\hline \multirow{2}{*}{\multicolumn{2}{|c|}{ Votes Ratio: Winner to Runner-Up, 1998}} & & & & $-6.092 * * *$ & $-5.961 * * *$ & & \\
\hline & & & & & [1.942] & [1.565] & & \\
\hline \multirow[t]{2}{*}{ Medieval Port x Votes Ratio 1998} & & & & & 2.450 & 2.572 & & \\
\hline & & & & & [3.682] & [3.371] & & \\
\hline \multirow[t]{2}{*}{ BJP vote share 1998} & & & & & & & $-0.560 * * *$ & $-0.576^{* * *}$ \\
\hline & & & & & & & [0.083] & {$[0.074]$} \\
\hline \multicolumn{2}{|l|}{ Medieval Port x BJP vote share 1998} & & & & & & 0.177 & $0.255^{*}$ \\
\hline & & & & & & & {$[0.125]$} & {$[0.125]$} \\
\hline \multirow[t]{2}{*}{ Town Muslim- founded or capital } & & 3.164 & & 2.472 & & -0.419 & & 1.787 \\
\hline & & [2.924] & & [3.713] & & [3.879] & & [3.267] \\
\hline \multirow[t]{2}{*}{ Centuries Muslim Rule (to 1707) } & & $3.618^{* * *}$ & & $3.834 * * *$ & & $1.909 *$ & & $3.279 * * *$ \\
\hline & & [0.835] & & [1.168] & & [0.976] & & {$[0.930]$} \\
\hline \multirow[t]{2}{*}{ Hindu Colonial Ruler } & & 2.981 & & 0.705 & & -0.087 & & 2.328 \\
\hline & & [1.769] & & [2.111] & & [2.264] & & {$[2.020]$} \\
\hline \multirow[t]{2}{*}{ Muslim Colonial Ruler } & & 5.544 & & 6.141 & & 6.238 & & 5.805 \\
\hline & & [4.165] & & [6.325] & & [6.949] & & [4.502] \\
\hline \multirow{2}{*}{\multicolumn{2}{|c|}{ \% Partition Majority Inflows (1931-51) }} & -1.223 & & -0.888 & & -0.861 & & -1.347 \\
\hline & & {$[0.801]$} & & [0.861] & & [0.839] & & {$[0.871]$} \\
\hline \multirow{2}{*}{\multicolumn{2}{|c|}{ \% Partition Muslim Outflows (1931-51) }} & $-1.273 * *$ & & -2.004 & & -1.361 & & -1.439 \\
\hline & & {$[0.462]$} & & [1.849] & & [1.751] & & [1.303] \\
\hline \multirow{2}{*}{\multicolumn{2}{|c|}{ Prop. Scheduled Tribe in Town }} & $-0.453^{* * *}$ & & -0.182 & & -0.190 & & $-0.428 *$ \\
\hline & & [0.103] & & {$[0.161]$} & & {$[0.171]$} & & {$[0.226]$} \\
\hline \multirow{2}{*}{\multicolumn{2}{|c|}{ Prop. Scheduled Caste in Town }} & -0.149 & & 0.006 & & 0.022 & & -0.044 \\
\hline & & {$[0.261]$} & & {$[0.270]$} & & {$[0.274]$} & & {$[0.246]$} \\
\hline \multirow{2}{*}{\multicolumn{2}{|c|}{ Active port in 2001}} & $5.835^{*}$ & & 5.403 & & 5.589 & & 4.451 \\
\hline & & [3.186] & & [4.335] & & [3.910] & & [3.143] \\
\hline \multirow{2}{*}{\multicolumn{2}{|c|}{ Workers Participation Rate }} & 0.013 & & -0.131 & & -0.150 & & -0.026 \\
\hline & & {$[0.141]$} & & {$[0.152]$} & & {$[0.160]$} & & [0.113] \\
\hline \multirow{2}{*}{\multicolumn{2}{|c|}{ Literacy Rate }} & -0.031 & & -0.049 & & -0.034 & & 0.008 \\
\hline & & {$[0.160]$} & & {$[0.166]$} & & [0.165] & & {$[0.150]$} \\
\hline \multirow{2}{*}{\multicolumn{2}{|c|}{ Prop. Muslim in Town, 1981}} & $38.632 * *$ & & 26.332 & & $24.890 *$ & & 13.771 \\
\hline & & [18.185] & & [17.328] & & [13.910] & & [14.007] \\
\hline \multirow{2}{*}{\multicolumn{2}{|c|}{ Prop. Muslim in Town ${ }^{2}, 1981$}} & -46.371 & & -34.608 & & -34.037 & & -21.074 \\
\hline & & [28.477] & & {$[25.605]$} & & {$[24.112]$} & & [22.540] \\
\hline \multicolumn{2}{|l|}{ Joint-F Med Port vars. } & & & & 5.58 & 2.75 & 5.89 & 4.2 \\
\hline \multicolumn{2}{|l|}{ Prob $>F$} & & & & 0.01 & 0.09 & 0.01 & 0.03 \\
\hline$\overline{\text { District FE }}$ & $\mathrm{N}$ & $\mathrm{N}$ & $\mathrm{Y}$ & $\mathrm{Y}$ & $\mathrm{Y}$ & $\bar{Y}$ & $\mathrm{Y}$ & $\bar{Y}$ \\
\hline Observations & 180 & 180 & 180 & 180 & 180 & 180 & 180 & 180 \\
\hline R-squared & 0.35 & 0.48 & 0.57 & 0.61 & 0.61 & 0.65 & 0.72 & 0.76 \\
\hline
\end{tabular}

Notes: All regressions include log. distances from navigable rivers, coastal town, Natural Disasters, log. population (1991), Class of town (I,II,III), distance to Godhra (100,200,300km) and, where noted, 1991 district fixed effects. Historical controls include: Centuries Muslim rule, Muslimfounded or capital, \% Partition Hindu/ Sikh Inflows and Muslim Outflows. Contemporaneous controls include: Proportion SC/ST, Modern active port, Literacy Rate, Worker's Participation Rate, Proportion Muslim 1981 (and a quadratic term). All values observed in 1991 unless noted. Robust standard errors in brackets (clustered at 1991 district): * significant at 10\%; ** 5\%; *** $1 \%$ 


\section{Table 8: Regression: Probability of Ruling Party (BJP) Seat Victory, 2002}

\begin{tabular}{|c|c|c|c|c|c|c|}
\hline & (1) & (2) & (3) & (4) & (5) & (6) \\
\hline \multirow[t]{2}{*}{ Medieval Port } & $-0.178 *$ & $-0.216^{*}$ & -0.140 & -0.217 & $-0.908 * *$ & $-1.376^{* * *}$ \\
\hline & [0.096] & {$[0.110]$} & [0.448] & [0.415] & {$[0.373]$} & [0.429] \\
\hline \multirow[t]{2}{*}{ Votes Ratio: Winner to Runner-Up, 1998} & & & 0.090 & 0.144 & & \\
\hline & & & [0.079] & [0.115] & & \\
\hline \multirow{2}{*}{ Medieval Port x Votes Ratio 1998} & & & -0.037 & -0.021 & & \\
\hline & & & [0.281] & [0.250] & & \\
\hline \multirow[t]{2}{*}{ BJP vote share 1998} & & & & & $0.014^{* * *}$ & $0.013^{* * *}$ \\
\hline & & & & & {$[0.004]$} & {$[0.004]$} \\
\hline \multirow[t]{2}{*}{ Medieval Port x BJP vote share 1998} & & & & & $0.014^{*}$ & $0.021 * *$ \\
\hline & & & & & [0.007] & {$[0.008]$} \\
\hline \multirow[t]{2}{*}{ Town Muslim- founded or capital } & & 0.262 & & 0.372 & & $0.443^{*}$ \\
\hline & & {$[0.254]$} & & {$[0.255]$} & & [0.233] \\
\hline \multirow[t]{2}{*}{ Centuries Muslim Rule (to 1707) } & & 0.012 & & 0.059 & & 0.031 \\
\hline & & [0.073] & & [0.091] & & [0.077] \\
\hline \multirow{2}{*}{ Hindu Colonial Ruler } & & 0.123 & & 0.122 & & 0.063 \\
\hline & & [0.148] & & [0.162] & & [0.147] \\
\hline \multirow[t]{2}{*}{ Muslim Colonial Ruler } & & $0.359 *$ & & $0.329 *$ & & $0.417^{* *}$ \\
\hline & & [0.193] & & [0.189] & & {$[0.174]$} \\
\hline \multirow[t]{2}{*}{ \% Partition Majority Inflows (1931-51) } & & -0.073 & & -0.110 & & -0.104 \\
\hline & & {$[0.061]$} & & {$[0.075]$} & & [0.073] \\
\hline \multirow[t]{2}{*}{ \% Partition Muslim Outflows (1931-51) } & & $-0.172 * *$ & & $-0.180 * *$ & & $-0.179 * *$ \\
\hline & & {$[0.076]$} & & {$[0.075]$} & & {$[0.068]$} \\
\hline Joint-F Med Port vars. & & & 2.03 & 2.84 & 5.97 & 8.94 \\
\hline Prob $>F$ & & & 0.16 & 0.09 & 0.01 & 0.00 \\
\hline District FE & $\mathrm{Y}$ & $\mathrm{Y}$ & $\mathrm{Y}$ & $\mathrm{Y}$ & $\bar{Y}$ & $\bar{Y}$ \\
\hline Observations & 182 & 182 & 180 & 180 & 180 & 180 \\
\hline R-squared & 0.31 & 0.38 & 0.31 & 0.41 & 0.4 & 0.49 \\
\hline
\end{tabular}

Notes: All regressions include log. distances from navigable rivers, coastal town, Natural Disasters, log. population (1991), Class of town (I,II,III), distance to Godhra (100,200,300km) and, where noted, 1991 district fixed effects. Historical controls include: Centuries Muslim rule, Muslimfounded or capital, \% Partition Hindu/ Sikh Inflows and Muslim Outflows. Contemporaneous controls include: Proportion SC/ST, Modern active port, Literacy Rate, Worker's Participation Rate, Proportion Muslim 1981 (and a quadratic term). All values observed in 1991 unless noted. Robust standard errors in brackets (clustered at 1991 district): * significant at 10\%; ** 5\%; *** $1 \%$ 
Table 9: Regression: Winner:Runner Up Vote Share Ratio, 2002 and 2007 State Elections

\begin{tabular}{|c|c|c|c|c|c|c|c|c|}
\hline & (1) & (2) & (3) & (4) & (5) & (6) & (7) & (8) \\
\hline & \multicolumn{4}{|c|}{ Winner: Runner Up Vote Ratio, 2002} & \multicolumn{4}{|c|}{ Winner: Runner Up Vote Ratio, 2007} \\
\hline \multirow[t]{2}{*}{ Medieval Port } & -0.555 & $-1.230 * *$ & -0.551 & $-1.413^{* * *}$ & $-1.656 * * *$ & $-1.897 * * *$ & $-1.015^{* *}$ & $-1.163^{*}$ \\
\hline & {$[0.353]$} & {$[0.433]$} & {$[0.388]$} & {$[0.471]$} & {$[0.418]$} & {$[0.579]$} & {$[0.464]$} & {$[0.568]$} \\
\hline \multirow[t]{2}{*}{ Medieval Port x BJP vote share 1998} & $0.012^{*}$ & $0.023^{* *}$ & 0.010 & $0.025^{* *}$ & $0.035^{* * *}$ & $0.038^{* * *}$ & $0.023^{* *}$ & $0.025^{* *}$ \\
\hline & {$[0.007]$} & [0.009] & {$[0.008]$} & {$[0.009]$} & {$[0.009]$} & {$[0.011]$} & {$[0.009]$} & {$[0.011]$} \\
\hline \multirow{2}{*}{ BJP vote share 1998} & 0.007 & 0.005 & 0.008 & 0.008 & -0.003 & -0.004 & -0.002 & -0.003 \\
\hline & {$[0.004]$} & [0.004] & {$[0.006]$} & {$[0.005]$} & [0.005] & [0.005] & {$[0.006]$} & {$[0.006]$} \\
\hline \multirow[t]{2}{*}{ Town Muslim- founded or capital } & & $0.387^{* *}$ & & $0.419 * *$ & & 0.047 & & -0.006 \\
\hline & & {$[0.147]$} & & [0.164] & & [0.285] & & [0.392] \\
\hline \multirow[t]{2}{*}{ Centuries Muslim Rule (to 1707) } & & 0.032 & & 0.101 & & 0.021 & & 0.042 \\
\hline & & [0.045] & & [0.094] & & [0.085] & & {$[0.140]$} \\
\hline \multirow[t]{2}{*}{ \% Partition Majority Inflows (1931-51) } & & $-0.055^{*}$ & & -0.011 & & $0.086^{* *}$ & & $0.117^{* * *}$ \\
\hline & & [0.029] & & {$[0.028]$} & & {$[0.038]$} & & {$[0.024]$} \\
\hline \multirow[t]{2}{*}{ \% Partition Muslim Outflows (1931-51) } & & 0.018 & & 0.053 & & -0.036 & & 0.026 \\
\hline & & {$[0.011]$} & & {$[0.046]$} & & [0.041] & & [0.059] \\
\hline Joint-F Med Port vars. & 1.99 & 4.41 & 1.01 & 4.89 & 8.36 & 6.2 & 3.51 & 2.97 \\
\hline Prob $>F$ & 0.17 & 0.03 & 0.38 & 0.02 & 0 & 0.01 & 0.05 & 0.08 \\
\hline District FE & $\mathrm{N}$ & $\mathrm{N}$ & $\mathrm{Y}$ & $\mathrm{Y}$ & $\mathrm{N}$ & $\mathrm{N}$ & $\mathrm{Y}$ & $\mathrm{Y}$ \\
\hline Observations & 180 & 180 & 180 & 180 & 180 & 180 & 180 & 180 \\
\hline R-squared & 0.31 & 0.42 & 0.49 & 0.55 & 0.27 & 0.37 & 0.48 & 0.57 \\
\hline
\end{tabular}

Notes: All regressions include log. distances from navigable rivers, coastal town, Natural Disasters, log. population (1991), Class of town (I,II,III), distance to Godhra $(100,200,300 \mathrm{~km})$ and, where noted, 1991 district fixed effects. (2) and (4) include: Centuries Muslim rule, Muslim-founded or capital, \% Partition Hindu/ Sikh Inflows and Muslim Outflows. Contemporaneous controls include: Proportion SC/ST, Modern active port, Literacy Rate, Worker's Participation Rate, Proportion Muslim 1981 (and a quadratic term). All values observed in 1991 unless noted. Robust standard errors in brackets (clustered at 1991 district): $*$ significant at $10 \% ; * * 5 \%$;** $1 \%$

Table 10: Correlation of Winner:Runner Up Vote Share Ratios, 1990-2007

\begin{tabular}{|c|c|c|c|c|c|c|}
\hline & 2007 & 2002 & 1998 & 1995 & 1990 & Largest Parties in the Vidhan Sabha \\
\hline 2007 & 1 & & & & & Bharatiya Janata Party \\
\hline 2002 & $0.4095 * * *$ & 1 & & & & Bharatiya Janata Party \\
\hline 1998 & $0.1424 *$ & $0.1816^{* *}$ & 1 & & & Bharatiya Janata Party \\
\hline 1995 & -0.1046 & $0.1572 * *$ & $0.2419 * * *$ & 1 & & Bharatiya Janata Party \\
\hline 1990 & -0.0356 & 0.0667 & $0.2771 * * *$ & -0.0243 & 1 & Janata Dal \\
\hline
\end{tabular}

Winner: Runner-Up Ratios; * significant at $10 \% ; * * 5 \% ; * * * 1 \%$ 


\section{Discussion}

This paper argues that there exists a fundamentally conditional, yet magnifying interaction between electoral competition and local institutions in generating incentives for ethnic violence. Where marginal electoral constituencies coincide with or reflect pre-existing historic inter-ethnic economic competition- as occurred in Gujarat from 1998-2002, politicians gained both local and state-wide incentives to foster ethnic mobilization and violence. Indeed, the patterns of violence and the resulting vote swings to the ruling party suggest that riots played an effective role in gaining that party the support of these marginal constituencies.

Yet, by doing so, electoral competition appears to have shifted as well. This allows us to examine whether the corollary is also true: state politicians seeking to compete in marginal constituencies with strong local institutions of tolerance should face incentives to emphasise these voters' preferences more relative to their more polarized constituents, leading potentially to a de-escalation in state-wide platforms of ethnic hatred.

Indeed, five years after the Gujarat riots, in 2007, the state prepared itself for another election. Yet despite facing increased electoral competition in many constituencies throughout the state (Figure 4), there was no surge in electoral rioting in the state and the incidence of riots remained below the levels of rioting that had occurred even non-election years prior to the pogrom. These reductions were state-wide, affecting both medieval and non-medieval port districts (Figure 1). Narendra Modi, the Chief Minister, campaigned explicitly on a platform of economic development, with ethnic mobilization conspicuously absent from the ruling party platform. ${ }^{20}$ Dissident elements in the state ruling party, including alleged stalwarts of the 2002 riots like the then state home minister, rallied against the party leadership, accusing the Chief Minister of betraying the Hindu community and no longer being worthy of the honorific "Hindu Hriday Samrat" (Emperor of Hindu Hearts). ${ }^{21}$ Instead, observers noted that Modi explicitly reached out in his election campaign to Muslims from the Memon, Khoja and Bohra communities, each of whom had their origins in India as medieval traders (Engineer, 2008). ${ }^{22}$ In a remarkable reversal, de-emphasizing ethnic mobilizing appears to have

\footnotetext{
${ }^{20} \mathrm{In}$ an interview to the Hindu newspaper, when "asked where Muslims figured in his vision of Gujarat, he flared up: I don't like this thinking. I work for five-and-a-half crore Gujaratis. For me, anyone who lives here is a Gujarati, and I will not allow politics to come into this." Vidya Subramaniam, "The Muslim Question in Gujarat" The Hindu, October 9th, 2007.

${ }^{21}$ Ibid. In fact it would be the Congress party, not the BJP, that would raise the 2002 violence in its election campaign, with Sonia Gandhi referring to support the BJP as "maut ka saudagar"-a "bargain with death".

${ }^{22}$ While accounts agree that these groups were viewed as marginal constituencies, accounts differ on why these communities were plausibly persuadable despite the pogroms in which they also were targeted. Engineer (2008), himself a prominent left-wing dissident Bohra, argues that Bohras and other Gujarati Muslim trading communities "are rich traders and they will be as much attracted by the development discourse as upper caste Hindu Gujaratis." In contrast, the Bohra activist J.S. Bandukwala claims that: "The Syedna [the
} 
helped the BJP win an unprecedented third term in 2007 and a fourth term in 2012, with a significant degree of Muslim support, particularly among trading communities, and even winning in Muslim majority constituencies, without having fielded a single Muslim candidate. Like Uhuru Kenyatta, another alleged orchestrator of ethnic violence, Narendra Modi has gone from being internationally-reviled and potentially subject to criminal prosecution for his alleged role in state-sponsored pogroms to being seen as a credible Prime Ministerial candidate.

Could it be that the anonymous police officer in Ahmadabad was right, that the ethnic violence in 2002, arguably India's worst since the Partition, was 'unfinished business' that would result in less ethnic tension thereafter? That officer's view, like that of some in the Jim Crow South (Bleakley and Owens, 2010) was that the minority would 'learn its place', and cease to compete for political patronage or resources. Though the broad patterns of riots over time do appear consistent to an extent with his view, this paper suggests that this interpretation is incomplete. While the ethnic cleansing and terrorizing of minority populations in areas of Gujarat where Hindus and Muslims have long competed may have taught those local minorities to fear and to flee, it also appears to have left these areas inframarginal in subsequent elections, and no longer as relevant to state politics or platforms. And it does not appear that opponents of violent ethnic domination- whether among the ethnic minority or the majority - 'learned their place': towns with a long history of interethnic tolerance voted strongly against the ruling party in the aftermath of the violence, when such action might yet have proven dangerous and costly. By doing so, they may have also subsequently rendered themselves electorally more competitive and thus influential to the stance of state-wide political platforms on the issue of ethnic mobilization. Electoral competition has long been seen as a source of ethnic mobilization and violence. Yet, even in highly ethnically-polarized states, when electoral competition becomes located among communities with local traditions of tolerance and inter-ethnic trust, such competition may actually generate broader beneficial spillovers of peace.

Bohra's spiritual leader] will always seek a cordial relation with the party in power. It is in his interests, and as he sees it, in the interests of the community". See Raheel Dhattiwala "Muslim as BJP supporter in Gujarat", The Hindu, 2013. 


\section{References}

al-Din al Malibari, Zayn, Tohfut-ul-mujahideen, London: Oriental Translation Fund of Great Britain, 1528. translated from the Arabic by Rowlandson, M.J. in 1833.

Alberuni, Abu-Raihan Muhammad Ibn Ahmad, Indica, 2005 ed., Delhi: Munshiram Manoharlal, 1030. edited by Sachau, Edward C.

Alesina, Alberto and Eliana La Ferrara, "Ethnic diversity and economic performance," Journal of Economic Literature, 2005, 43 (3), 762-800.

Banerjee, Abhijit, Lakshmi Iyer, and Rohini Somanathan, "Public Action for Public Goods," in T. Paul Schultz and John Strauss, eds., Handbook of Development Economics, Vol. 4, Elsevier, 2008.

Barbosa, Duarte, A description of the coasts of East Africa and Malabar in the beginning of the sixteenth century, London: Hakluyt Society, 1519. translated from the Portuguese by Stanley, Henry E. J. in 1866.

Beaman, Lori, Raghabendra Chattopadhyay, Esther Duflo, Rohini Pande, and Petia Topalova, "Powerful women: does exposure reduce bias?," Quarterly Journal of Economics, 2009, 124 (4), 1497-1540.

Becker, Sasha O., Katrin Boeckh, Christa Hainz, and Ludiger Woessmann, "The empire is dead, long live the empire! Long-run persistence of trust and corruption in the bureaucracy.," CEPR Discussion Paper 8288, 2012.

Bharadwaj, Prashant, Asim Khwaja, and Atif Mian, "The Big March: Migratory Flows After the Partition of India," Economic and Political Weekly, August 2008, 43 (35).

_ , _, and _ , "The Partition of India: demographic consequences," October 2008. Harvard Kennedy School.

Blake, Stephen P., Shahjahanabad : the sovereign city in Mughal India, 1639- 1739, Cambridge University Press, 1991.

Blakeslee, David, "Propaganda and Ethno-Religious Politics in Developing Countries: Evidence from India," May 2013. mimeo, Columbia.

Bleakley, Hoyt and Emily Owens, "Violence Beyond Reason: Prohibition of Alcohol and the Decline of Lynching in the US South," 2010. mimeo, Chicago GSB.

Bohlken, Anjali Thomas and Ernest Sergenti, "Ethnic Violence and Economic Growth: An Empirical Investigation of Hindu-Muslim Riots in India," Journal of Peace Research, forthcoming.

Brass, Paul R., Theft of an Idol, Princeton, NJ: Princeton University Press, 1997.

_, The production of Hindu-Muslim violence in contemporary India, Seattle: University of Washington Press, 2003. 
Burman, J.J. Roy, Gujarat Unknown: Hindu-Muslim syncretism and humanistic forays, New Delhi: Mittal, 2005.

Canes-Wrone, Brandice, Michael Herron, and Kenneth Shotts, "Leadership and Pandering: A Theory of Executive Policymaking," American Journal of Political Science, July 2001, $45(3), 532-550$.

Casson, Lionel, ed., The Periplus Maris Erythraei, Princeton: Princeton, 1989.

Caughey, Devin and Jasjeet S. Sekhon, "Elections and the Regression Discontinuity Design: Lessons from Close U.S. House Races, 19422008," Political Analysis, 2011, 19, $385-408$.

Chakravarti, Ranabir, "Nakhudas and Nauvittakas: ship-owning merchants in the West Coast of India (C. AD 1000-1500)," Journal of the Economic and Social History of the Orient, February 2000, 43 (1), 34-64.

Chandra, Kanchan, Why Ethnic Parties Succeed: Patronage and Ethnic Head Counts in India, Cambridge University Press, 2007.

Chaudhuri, K.N., Trade and civilisation in the Indian Ocean : an economic history from the rise of Islam to 1750, Cambridge: Cambridge University Press, 1995.

Chen, Daniel, "Club Goods and Group Identity: Evidence from Islamic Resurgence During the Indonesian Financial Crisis," Journal of Political Economy, 2010, 118 (2), 300-354.

Cox, Gary W. and Michael Munger, "Closeness, Expenditures, and Turnout in the 1982 U.S. House Elections," American Political Science Review, March 1989, 83 (1), 217-231.

di Verthema, Ludovico, "The nauigation and voyages of Lewes Vertomannus, gentleman to the citie of Rome, Hakluyt, 1503. transl. from the Latin by Eden, Richard, 1576.

Diaz-Cayeros, Alberto and Saumitra Jha, "Can Contract Failures Lead to Ethnic Assimilation? Evidence from Cochineal in Mexico," February 2013. mimeo, Stanford Graduate School of Business.

Easterly, William and Ross Levine, "Africa's growth tragedy: policies and ethnic divisions," Quarterly Journal of Economics, 1997, 111 (4), 1203-1250.

Eifert, Benn, Edward Miguel, and Daniel N. Posner, "Political Competition and Ethnic Identification in Africa," American Journal of Political Science, April 2010, 54 (2), $494-510$.

Engineer, Asghar Ali, "Gujarat Elections and Aftermath," Secular Perspective, January 1-15 2008.

Esteban, Joan and Debraj Ray, "On the salience of ethnic conflict," February 2007. working paper, NYU, available at: www.econ.nyu.edu/user/debraj/Papers/EstebanRaySalience.pdf. 
Fair, C. Christine, Neil A. Malhotra, and Jacob N. Shapiro, "Democratic Values and Support for Militant Politics: Evidence from a National Survey of Pakistan," Journal of Conflict Resolution, 2013.

Fearon, James D. and David D. Laitin, "Ethnicity, insurgency and civil war," American Political Science Review, 2003, 97 (1), 75-90.

Ferishta, Muhammad Kasim, The History of Hindustan, 2nd ed., New Delhi: Dahinam Publishers, 1620. Translated from the Persian by Alexander Dow, 1770, and edited by B.S. Dahiya, 2003.

Field, Erica, Matthew Levinson, Rohini Pande, and Sujata Visaria, "Segregation, rent control and riots: the economics of religious conflict in an Indian city," American Economic Review: Papers and Proceedings, May 2008, 98 (2), 501-509.

Gerber, Alan, Jonathan Gruber, and Daniel Hungerman, "Does church attendance cause people to vote? Using blue laws' repeal to estimate the effect of religiosity on voter turnout," 2010. mimeo, Notre Dame.

Gillion, Kenneth L., Ahmedabad: A Study in Indian Urban History, Berkeley: University of California Press, 1968.

Glaeser, Edward L., "The political economy of hatred," Quarterly Journal of Economics, January 2005, 120 (1), 45-86.

Grosfeld, Irena and Ekaterina Zhuravskaya, "Persistent effects of empires: Evidence from the partitions of Poland," February 2012. mimeo.

Grosjean, Pauline, "The institutional legacy of the Ottoman Empire: Islamic rule and financial development in South Eastern Europe," Journal of Comparative Economics, 2012, 39 (1), 1-16.

Guiso, Luigi, Paola Sapienza, and Luigi Zingales, "Long Term Persistence," working paper 08-11, Chicago GSB 2008.

Hansen, Thomas Blom, The Saffron Wave: Democracy and Hindu Nationalism in Modern India, Princeton University Press, 1999.

Hearn, Paul, "Global GIS database. Digital atlas of South Asia," electronic resource 2001. US Geological Survey digital data series.

Ibn Battuta, Abu Abdullah, The travels of Ibn Battuta, 1971 ed., New York: Lenox Hill, 1355. translated from the Arabic by Lee, Samuel, 1829.

Jha, Saumitra, "Trade, institutions and religious tolerance: evidence from India," GSB Research Paper 2004, Stanford Graduate School of Business, Stanford CA January 2008.

_ , "Analyzing Political Risk in Developing Countries: A Practical Framework for Project Managers," Business and Politics, April 2013, 15 (1), 117-136. 
_., "Trade, institutions and ethnic tolerance: evidence from South Asia," American Political Science Review, forthcoming.

- and Steven I. Wilkinson, "Does Combat Experience Foster Organizational Skill? Evidence from Ethnic Cleansing during the Partition of South Asia," American Political Science Review, November 2012.

Jukua, Chau, His work on the Chinese and Arab trade in the twelfth and thirteenth centuries, entitled Chu-fan-chi, New York: Paragon Books, 1225. translated from the Chinese by Hirth, Friedrich and Rockhill, W.W. in 1966.

Miguel, Edward, Shanker Satyanath, and Ernest Sergenti, "Economic shocks and civil conflict: an instrumental variables approach," Journal of Political Economy, 2004, $112(4), 725-754$.

Mitra, A. and Debraj Ray, "Implications of an Economic Theory of Conflict: HinduMuslim Violence in India," 2010.

Montalvo, Jose G. and Marta Reynal-Querol, "Ethnic polarization, potential conflict and civil wars," American Economic Review, June 2005, 95 (3), 796-816.

Noe, Samuel V., "The walled city of Delhi," in Hooshang Amirahmadi and Salah S. El-Shakhs, eds., Urban development in the Muslim World, New Brunswick: Rutgers University, 1993.

Nunn, Nathan and Leonard Wantchekon, "The Slave Trade and the Origins of Mistrust in Africa," American Economic Review, forthcoming.

Olzak, Susan, The dynamics of ethnic competition and conflict, Stanford, CA: Stanford University Press, 1992.

Pathania, Vikram and Sharad Tandon, "Divisive Politics and Violence: Evidence from the Success of the Bharatiya Janata Party in India," 2011. mimeo, LSE.

People's Union for Democratic Rights, "Maaro! Kaapo! Baalo'! State, Society and Communalism in Gujarat," May 2002. mimeo.

Pyarelal, Mahatma Gandhi: The Early Years, Vol. 1, Ahmadabad: Navjivan Press, 1965.

Raychoudhari, Tapan, "The agrarian system of Mughal India: a review essay," in Muzaffar Alam and Sanjay Subrahmanyam, eds., The Mughal State, Delhi: Oxford University Press, 1998, chapter 8.

Schmidt, Karl J., Atlas and survey of South Asian history, New Delhi: Vision Books, 1999.

Sircar, D.C., "Veraval Inscription of Chaulukya-Vaghela Arjuna," Epigraphia Indica, 1962, XXXIV, 141. 
Subrahmanyam, Sanjay, The political economy of commerce: southern India, 1500-1650, Cambridge: Cambridge University Press, 1990.

Thapar, Romila, Somanatha: the many voices of a history, New Delhi, India: Penguin, 2004.

Varshney, Ashutosh, Ethnic Conflict and Civic Life: Hindus and Muslims in India, New Haven: Yale University Press, 2002.

_ and Steven I. Wilkinson, "Varshney Wilkinson Dataset on Hindu-Muslim Violence in India, Version 2," October 2004.

Voigtländer, Nico and Joachim Voth, "Persecution Perpetuated: The Medieval Origins of Anti-Semitic Violence in Nazi Germany," working paper 17113, NBER June 2011.

Wade, Robert, Village republics: economic conditions for collective action in South India, Oakland: ICS Press, 1988.

Wilkinson, Steven and Christopher Haid, "Ethnic Violence as Campaign Expenditure: Riots, Competition, and Vote Swings in India," 2009. mimeo.

Wilkinson, Steven I., Votes and violence: electoral competition and ethnic riots in India Cambridge studies in comparative politics, Cambridge: Cambridge University Press, 2004.

Yule, Sir Henry, ed., Cathay and the Way Thither, London: Hakluyt Society, 1866. 


\section{Appendix}

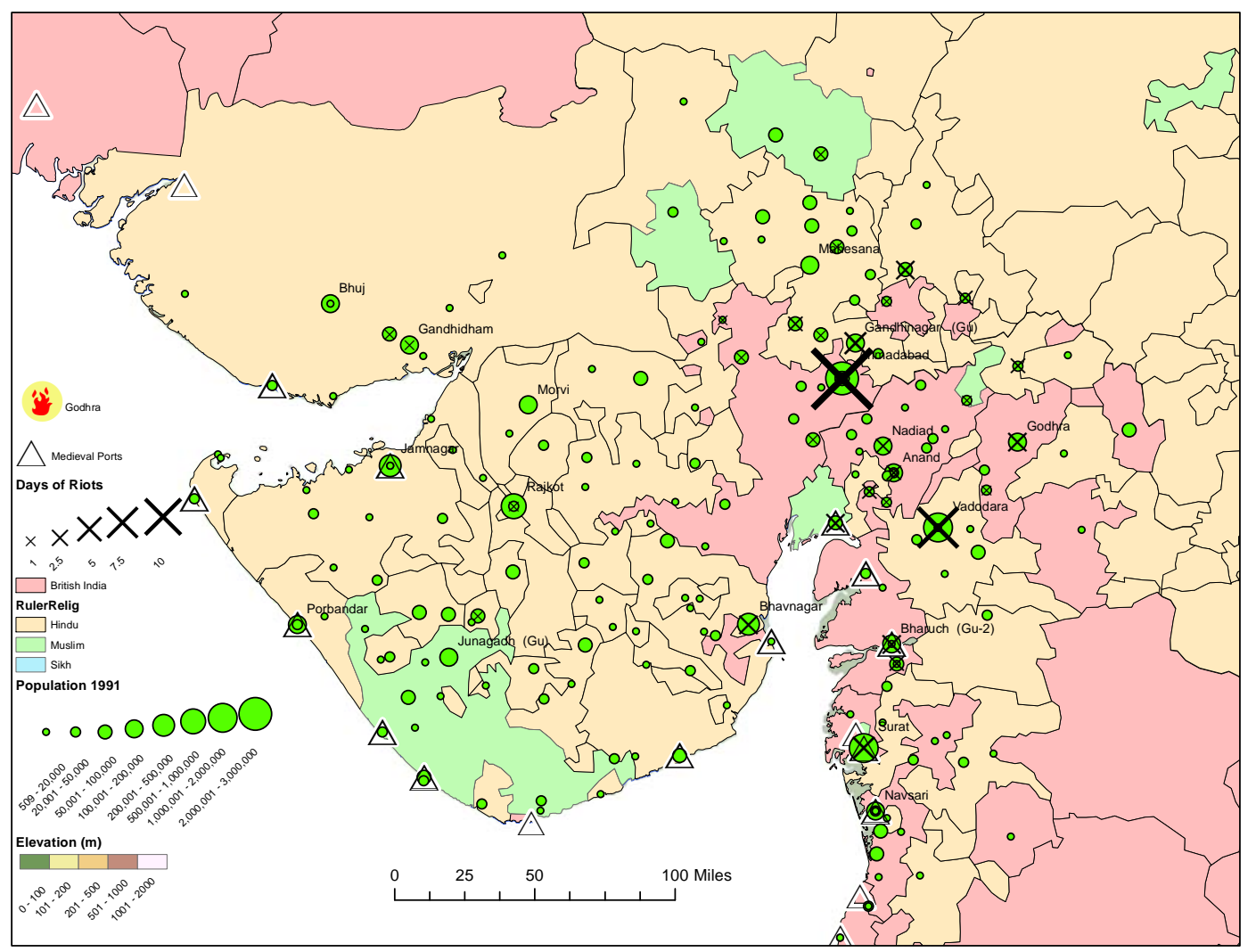

Figure 7: The Religion of Native Rulers in Gujarat, ca 1818-1947 


\section{Table 11: Effects on BJP vote share, 1998 Vidhan Sabha Elections:}

\begin{tabular}{|c|c|c|c|c|c|c|}
\hline & (1) & $(2)$ & (3) & (4) & (5) & (6) \\
\hline \multirow[t]{2}{*}{ Medieval trading port } & 2.264 & 2.640 & 3.347 & 2.089 & 2.496 & 4.153 \\
\hline & [3.279] & [3.462] & [3.605] & [2.944] & [3.101] & [3.475] \\
\hline \multirow{2}{*}{\multicolumn{2}{|c|}{ Town Muslim- founded or capital }} & -2.749 & -3.059 & & -1.736 & -3.504 \\
\hline & & [3.444] & [4.142] & & [4.876] & [4.214] \\
\hline \multirow{2}{*}{\multicolumn{2}{|c|}{ Centuries Muslim Rule (to 1707) }} & -1.253 & -1.087 & & -0.604 & -1.060 \\
\hline & & [1.044] & [1.268] & & [2.077] & [1.955] \\
\hline \multirow{2}{*}{\multicolumn{2}{|c|}{ Town under colonial Hindu ruler }} & 1.073 & 1.717 & & 0.652 & 2.872 \\
\hline & & [1.865] & [1.932] & & [3.213] & [2.021] \\
\hline \multirow{2}{*}{\multicolumn{2}{|c|}{ Town under colonial Muslim ruler }} & -0.370 & -0.630 & & -3.761 & -1.966 \\
\hline & & [1.866] & [3.896] & & [4.889] & [4.960] \\
\hline \multirow{2}{*}{\multicolumn{2}{|c|}{ \% Partition Majority Inflows (1931-1951) }} & & 0.537 & & & -0.690 \\
\hline & & & [0.793] & & & [0.610] \\
\hline \multirow{2}{*}{\multicolumn{2}{|c|}{ \% Partition Muslim Outflows (1931-1951) }} & & 0.475 & & & 0.989 \\
\hline & & & {$[0.547]$} & & & [1.507] \\
\hline \multirow{2}{*}{\multicolumn{2}{|c|}{ Prop. Scheduled Tribe in Town }} & & -0.159 & & & $-0.490 *$ \\
\hline & & & {$[0.172]$} & & & {$[0.276]$} \\
\hline \multirow{2}{*}{\multicolumn{2}{|c|}{ Prop. Scheduled Caste in Town }} & & -0.177 & & & -0.158 \\
\hline & & & {$[0.256]$} & & & {$[0.221]$} \\
\hline \multirow{2}{*}{\multicolumn{2}{|c|}{ Active port in 2001}} & & -3.722 & & & -3.754 \\
\hline & & & [3.937] & & & [4.024] \\
\hline \multirow{2}{*}{\multicolumn{2}{|c|}{ Workers Participation Rate }} & & 0.050 & & & 0.219 \\
\hline & & & {$[0.132]$} & & & [0.131] \\
\hline \multirow{2}{*}{\multicolumn{2}{|c|}{ Literacy Rate }} & & 0.134 & & & 0.107 \\
\hline & & & {$[0.124]$} & & & {$[0.136]$} \\
\hline \multirow{2}{*}{\multicolumn{2}{|c|}{ Prop. Muslim in Town, 1981}} & & -24.823 & & & -24.708 \\
\hline & & & [16.429] & & & [16.529] \\
\hline \multirow{2}{*}{\multicolumn{2}{|c|}{ Prop. Muslim in Town ${ }^{2}, 1981$}} & & 26.014 & & & $29.620^{*}$ \\
\hline & & & [19.442] & & & [16.941] \\
\hline District Fixed Effects & $\mathrm{N}$ & $\mathrm{N}$ & $\mathrm{N}$ & $\bar{Y}$ & $\bar{Y}$ & $\mathrm{Y}$ \\
\hline Observations & 180 & 180 & 180 & 180 & 180 & 180 \\
\hline R-squared & 0.22 & 0.23 & 0.29 & 0.34 & 0.35 & 0.41 \\
\hline
\end{tabular}

Notes: All regressions include log. distances from navigable rivers, coastal town, Natural Disasters, log. population (1991), Class of town (I,II,III), distance to Godhra $(100,200,300 \mathrm{~km})$ and, where noted, 1991 district fixed effects. Historical controls include: Centuries Muslim rule, Muslimfounded or capital, \% Partition Hindu/ Sikh Inflows and Muslim Outflows. Contemporaneous controls include: Proportion SC/ST, Modern active port, Proportion Muslim (and quadratic). Robust standard errors in brackets (clustered at 1991 district): * significant at 10\%; ** 5\%; *** $1 \%$ 